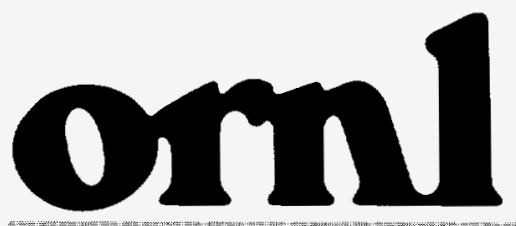

OAK RIDGE NATIONAL. LABORATORY
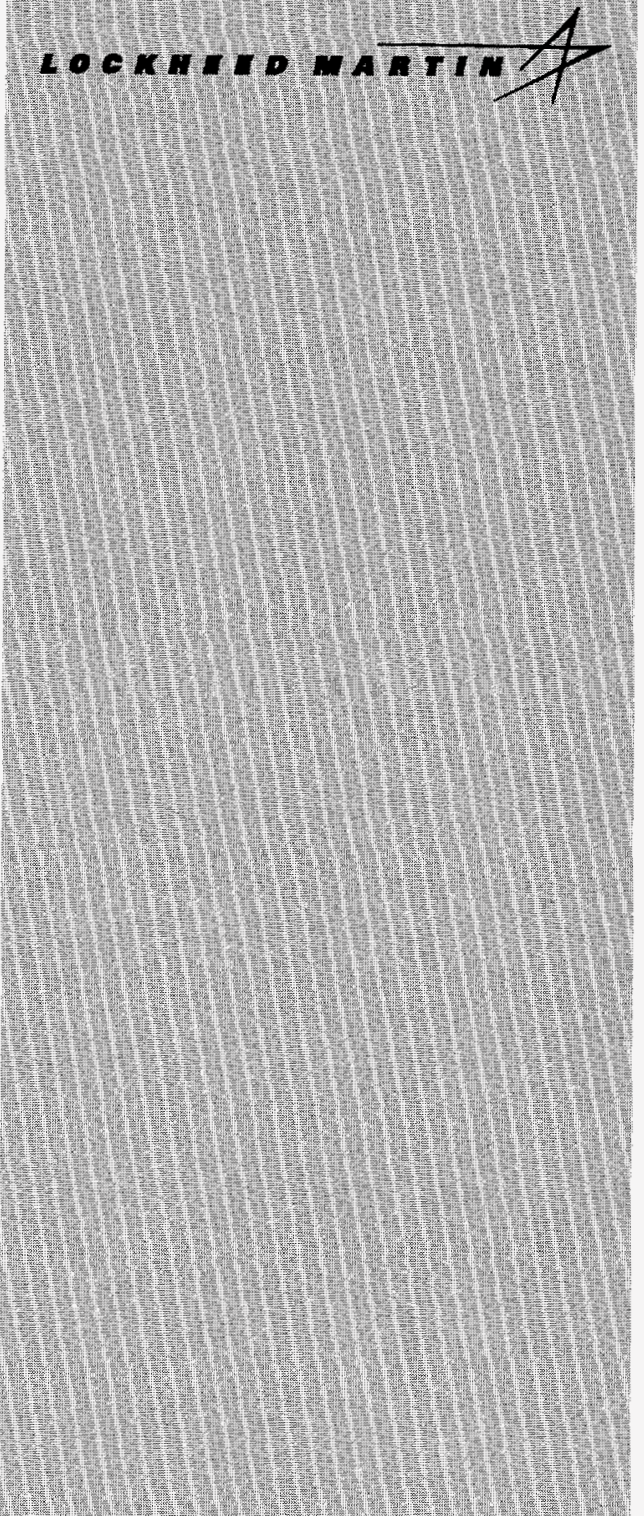

MANAGED BY LOCKHEED MARTIN ENERGY SYSTEMS, INC. FOR THE UNITED STATES DEPARTMENT OF ENERGY

\title{
Biomass Fuel from Woody Crops for Electric Power Generation
}

\author{
Robert D. Perlack \\ Lynn L. Wright \\ Michael A. Huston \\ William E. Schramm
}


This report has been reproduced directly from the best available copy.

Available to DOE and DOE contractors from the Office of Scientific and Technical Information, P.O. Box 62, Oak Ridge, TN 37831; prices available from (615) 576-8401, FTS 626-8401.

Available to the public from the National Technical Information Service, U.S. Department of Commerce, 5285 Port Royal Rd., Springfield, VA 22161.

This report was prepared as an account of work sponsored by an agency of the United States Government. Neither the United States Government nor any agency thereof, nor any of their employees, makes any warranty, express or implied, or assumes any legal liability or responsibility for the accuracy, completeness, or usefulness of any information, apparatus, product, or process disclosed, or represents that its use would not infringe privately owned rights. Reference herein to any specific commercial product, process, or service by trade name, trademark, manufacturer, or otherwise, does not necessarily constitute or imply its endorsement, recommendation, or favoring by the United States Government or any agency thereof. The views and opinions of authors expressed herein do not necessarily state or reflect those of the United States Government or any agency thereof. 


\section{DISCLAIMER}

Portions of this document may be illegible in electronic image products. Images are produced from the best available original document. 
Energy Division

\title{
BIOMASS FUEL FROM WOODY CROPS FOR ELECTRIC POWER GENERATION
}

\author{
Robert D. Perlack \\ Lynn L. Wright \\ Michael A. Huston \\ William E. Schramm \\ Biofuels Feedstock Development Program \\ Environmental Sciences Division
}

June 22, 1995

Prepared in Collaboration with

Winrock International

Biomass Energy Systems and Technology Project

Prepared by the

Oak Ridge National Laboratory

Oak Ridge, Tennessee 37831-6205

managed by

LOCKHEED MARTIN ENERGY SYSTEMS, INC.

for the

U.S. DEPARTMENT OF ENERGY

under contact DE-AC05-84OR21400

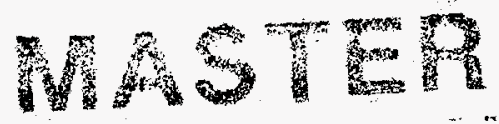





\section{TABLE OF CONTENTS}

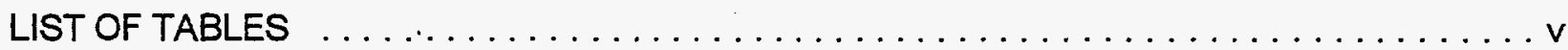

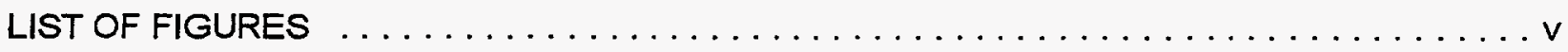

ACKNOWLEDGMENTS $\ldots \ldots \ldots \ldots \ldots \ldots \ldots \ldots \ldots \ldots \ldots \ldots \ldots \ldots \ldots$ vii

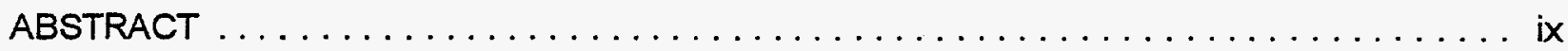

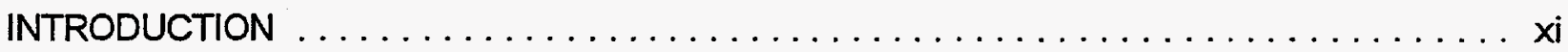

1. CASE STUDY EXPERIENCES WITH SHORT-ROTATION PLANTATIONS $\ldots \ldots \ldots \ldots \ldots 1$

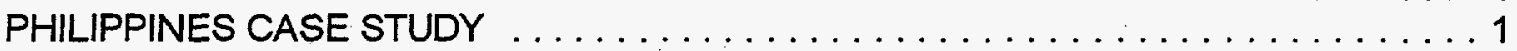

Plantation Management ...............................

Plantation Establishment, Tending and Protection ................ 2

Growth, Production, and Harvest $\ldots \ldots \ldots \ldots \ldots \ldots \ldots \ldots \ldots \ldots$

Observations .................................. 4

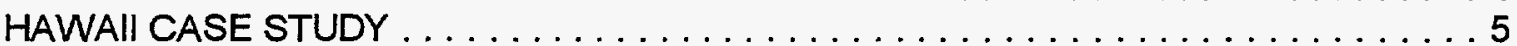

Plantation Management ........................... 5

Growth, Production, and Harvest $\ldots \ldots \ldots \ldots \ldots \ldots \ldots \ldots \ldots \ldots$

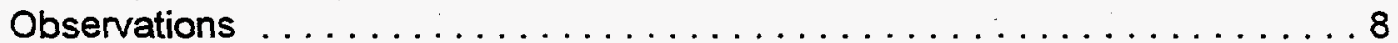

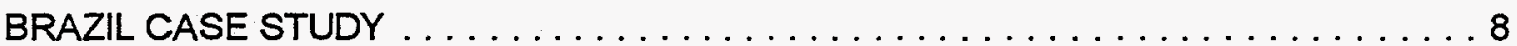

Plantation Management $\ldots \ldots \ldots \ldots \ldots \ldots \ldots \ldots \ldots \ldots \ldots \ldots$

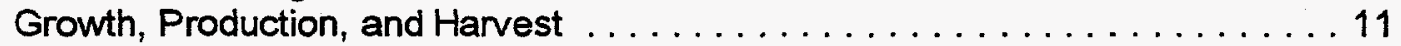

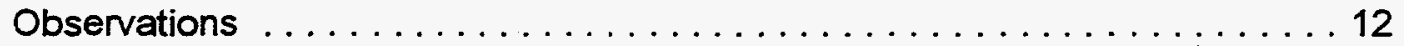

2. THE PRODUCTION OF SHORT-ROTATION WOODY CROPS $\ldots \ldots \ldots \ldots \ldots \ldots \ldots .13$

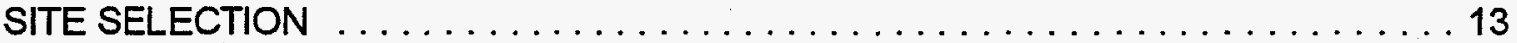

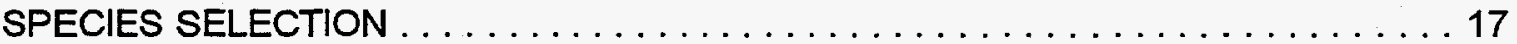

PLANTATION ESTABLISHMENT, TENDING, AND PROTECTION $\ldots \ldots \ldots \ldots \ldots 18$

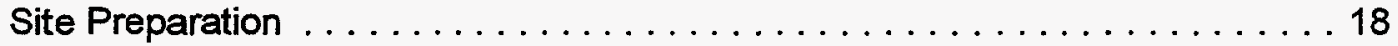

Seeds, Cuttings, and Nursery Operation $\ldots \ldots \ldots \ldots \ldots \ldots \ldots \ldots \ldots \ldots$

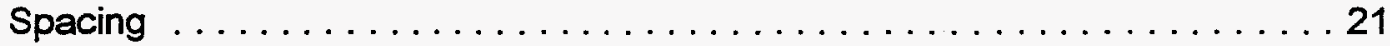

Planting $\ldots \ldots \ldots \ldots \ldots \ldots \ldots \ldots \ldots \ldots \ldots \ldots \ldots \ldots \ldots \ldots \ldots \ldots \ldots \ldots \ldots \ldots \ldots \ldots, 22$

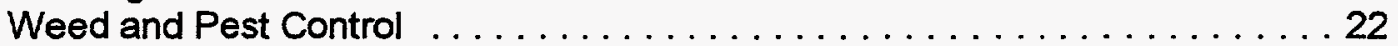

Protection from Fires and Animals $\ldots \ldots \ldots \ldots \ldots \ldots \ldots \ldots \ldots \ldots \ldots \ldots \ldots \ldots \ldots, 22$

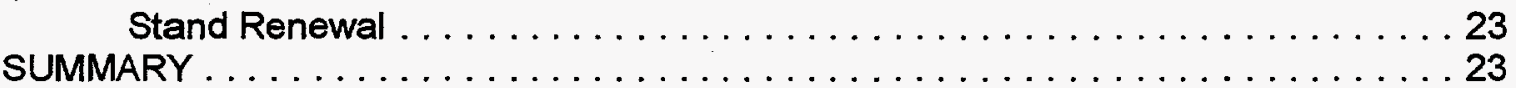

3. USE OF PLANTATION-GROWN BIOMASS FOR POWER GENERATION . . . . . . . 25

HARVESTING, TRANSPORT, STORAGE, HANDLING AND FUEL PREPARATION . . . 25

POWER GENERATION OPTIONS $\ldots \ldots \ldots \ldots \ldots \ldots \ldots \ldots \ldots \ldots \ldots \ldots \ldots \ldots$

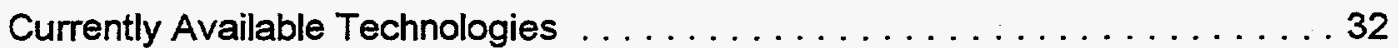

Emerging Technologies ........................... 33

4. ENVIRONMENTAL AND SOCIAL BENEFITS/COSTS OF BIOMASS PLANTATIONS …37

TREE PLANTATIONS AND SOILWATER ISSUES $\ldots \ldots \ldots \ldots \ldots \ldots . \ldots \ldots$

TREE PLANTATIONS AND BIODIVERSITY $\ldots \ldots \ldots \ldots \ldots \ldots \ldots \ldots \ldots 41$

TREE PLANTATIONS AND CHEMICAL POLLUTION ..............42 
TREE PLANTATIONS AND SOCIAL ECONOMICS

5. ECONOMICS OF PLANTATION-GROWN FUELS FOR POWER GENERATION . . . . . 45

THE COSTS OF PRODUCING AND HARVESTING PLANTATION FUELS . . . 45

THE COSTS OF POWER PRODUCTION FROM PLANTATION FUELS $\ldots \ldots 51$

CONCLUSIONS

NOTES AND REFERENCES 


\section{LIST OF TABLES}

Table 2.1. Plantation biomass annual production rates from around the world $\ldots \ldots \ldots \ldots 15$

Table 3.1. Productivity Summary of Machine and Manual Felling in Short Rotation,

Biomass Plantations . . . . . . . . . . . . . . . . . . . . . . . . 29

Table 4.1. Example carbon offsets from short-rotation plantation energy used for power

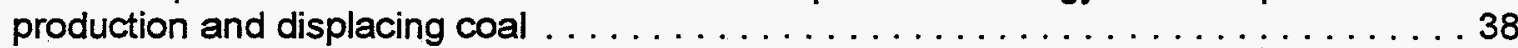

Table 5.1. Summary of the Costs and Productivity of Plantation-grown Fuel . . . . . . . 48

\section{LIST OF FIGURES}

Fig. 2.1. Annual production of wood and leaf biomass of natural forests across a latitudinal

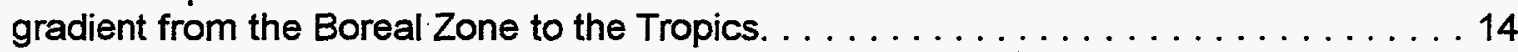

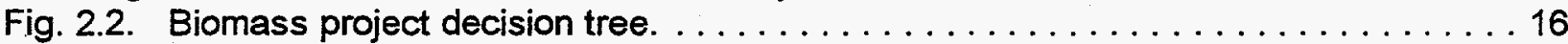

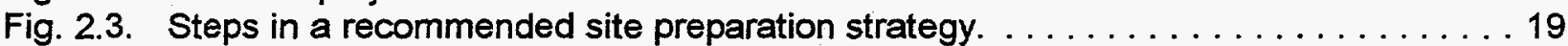

Fig. 3.1. Process diagram: plantation-grown biomass to power generation. . . . . . . . . 26

Fig. 3.2. A comparison of productivity and cost of harvesting systems for a large diameter $(15.2 \mathrm{~cm})$ and small diameter $(7.6 \mathrm{~cm})$ plantation stand. (1)

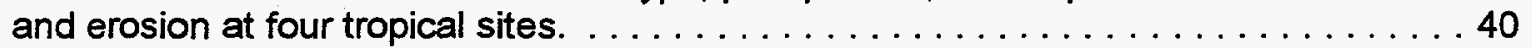

Fig. 5.1. The effect of biomass plant scale on feedstock requirements and transport distances.. . . . . . . . . . . . . . . . . . . . . . . . . . 46

Fig. 5.2. Variation in delivered feedstock costs by bioclimatic region in Northeast Brazil. . . . 49

Fig. 5.3. Average cost of plantation-grown feedstocks in Northeast Brazil. . . . . . . . . . 50

Fig. 5.4. The effect of fuel cost on power costs for a low-efficiency (conventional steamturbine) technology and a high-efficiency, low-capital cost technology. . . . . . . 52 



\section{ACKNOWLEDGMENTS}

This report was sponsored by the U.S. Agency for international Development (Office of Energy and Infrastructure), Winrock International, and the U.S. Department of Energy (Biofuels Systems Division). The authors want to thank Pat Layton (Scott paper Company), Vic Phillips (University of Hawaii), Robin Graham (ORNL), and Dan Wadell (National Rural Electric Cooperative Association) for their reviews and comments. 



\section{ABSTRACT}

BIOMASS FUEL FROM WOODY CROPS FOR ELECTRIC POWER GENERATION

This report discusses the biologic, environmental, economic, and operational issues associated with growing woody crops in managed plantations. Information on plantation productivity, environmental issues and impacts, and costs is drawn from DOE's Biofuels Feedstock Development as well as commercial operations in the U.S. and elsewhere. The particular experiences from three countries Brazil, the Philippines, and Hawaii (U.S.) - are discussed in considerable detail. 



\section{INTRODUCTION}

Biomass accounts for nearly $15 \%$ of world energy supplies. ${ }^{1}$ In industrialized countries, biomass supplies about $3 \%$, or 8 exajoules (EJ), of total primary energy. The dominant and fastest growing use of biomass fuels in industrialized countries is for process heat and electricity. ${ }^{2}$ In the developing countries, biomass fuel supplies about $48 \mathrm{EJ}$ or $35 \%$ of total primary energy. Most of this biomass energy is used traditionally for domestic cooking and space heating. However, where there are industrial and agricultural enterprises, wood, bagasse, rice hull, and other waste products are often used to generate heat for agricultural processes such as crop drying, steam to drive smallscale industrial processes, and electricity for on-site use and sometimes for off-site power sales.

The recent interest in converting biomass to electricity comes not only from its potential as a low-cost, indigenous supply of power, but for its potential environmental and developmental benefits. For example, biomass may be a globally important mitigation option to reduce the rate of $\mathrm{CO}_{2}$ buildup by sequestering carbon and by displacing fossil fuels. Renewably-grown biomass contributes only a very small amount of carbon to the atmosphere. Locally, plantations can lessen soil erosion, provide a means to restore degraded lands, offset emissions and local impacts from fossil-fired power generation (e.g., $\mathrm{SO}_{2}$ and $\mathrm{NQ}$ ), and, perhaps, reduce demands on existing forests. In addition to the direct power and environmental benefits, biomass energy systems offer numerous other benefits, especially for developing countries. Some of these benefits include the employment of underutilized labor and the production of co- and by-products (e.g., fuelwood).

Nearly all of the experience with biomass for power generation is based on the use of waste and residue fuels (primarily wood/wood wastes and agricultural residues). The production of electric power from plantation grown wood is an emerging technology with considerable promise. However, actual commercial use of plantation-grown fuels for power generation is limited to a few isolated experiences. Wood from plantations is not an inexpensive energy feedstock, and as long as worldwide prices of coal, oil and gas are relatively low, the establishment of plantations dedicated to supplying electric power or other higher forms of energy will occur only where financial subsidies or incentives exist or where other sources of energy are not available.

In countries where biomass plantations are supplying energy on a commercial basis, such as in Brazil, the Philippines and Sweden, it can be shown that a combination of government policies and/or high conventional energy prices have stimulated the use of short-rotation plantations for energy. Brazil used tax incentives beginning in the mid-1960s to initiate a reforestation program to provide for industrial wood energy and wood product needs. ${ }^{3}$ As a consequence of the Brazilian Forestry Code with its favorable tax incentives, the planted forest area in Brazil increased from 470,000 ha to 6.5 million ha by $1993 .{ }^{4}$ With the discontinuation of the tax incentives in 1988, plantation establishment in Brazil has slowed although the commercial feasibility of using eucalyptus for energy and other products has been clearly demonstrated. ${ }^{5}$ In Sweden, where district heating with wood is relatively common, the government used direct subsidies to farmers and by 1992 over 6,000 ha of commercial willow plantations had been planted. Government support was also used to provide extension services to farmers, distribute improved plant materials and contract with regional power plants to buy the biomass and fund an extensive research and development

program. ${ }^{6}$ The Dendro Thermal Power Program in the Philippines started off with a considerable amount of government support through farmer loan programs and technical assistance that resulted in nearly 18,000 ha of leucaena being planted in the early 1980 s. With the demise of government support in the mid-80's, and because of inadequate planning, poor technical decisions and inexperience with biomass energy systems, the program failed. Today, very little of the planted area is supplying feedstocks for electric power. ${ }^{7}$ 
The commercialization of short-rotation energy plantations are more likely to occur where market opportunities coincide with suitable crop production areas (i.e., availability of local expertise on soil and crop management, and locally adapted sources of selected fast-growing plant materials). In considering the potential for commercially viable biomass energy systems, it is necessary to think beyond conversion technologies, crop yield potential and site-specific production costs. To be successful developers must be cognizant of fuel prices; energy, environmental and agricultural policies; infrastructure support; financing arrangements; conversion technology requirements; potential risks; and local environmental conditions to make informed decisions about location, crop type and management approach. Successful ventures also require regional (or local) crop development and research activities to assure the availability of selected materials that are adapted to soils and climates of the region and the availability of knowledge and techniques for crop management.

This Report focuses on the biologic, environmental, economic and operational issues to be considered by decision makers contemplating the establishment of biomass plantations to provide fuel for power generation. Although some of the policy, social, and infrastructure issues will be alluded to, they are very country specific and difficult to treat generically. To provide context, three case studies are first discussed in Chapter 1. Chapter 2 considers concepts associated with plantation management that would apply to plantations established for nearly any purpose. Chapter 3 discusses harvest and handling technologies as well as electricity conversion technologies. Chapter 4 deals with environmental issues that must be considered in the establishment and harvesting of short-rotation wood plantations as well as social and environmental benefits of locally produced energy resources. Chapter 5 integrates the sections together by discussing the economics of producing wood for energy and the implications of scaling factors.

The information on plantation growth and environmental concerns used in this Report has largely been drawn from commercial experience in the production of short-rotation forests in the U.S. and Brazil and from research data generated by the Biofuels Feedstock Development Program in the U.S. and similar programs in Sweden, U.K. and other European countries. Information on the use of wood for energy has largely been drawn from available information on biomass energy projects using wood wastes and residues. 


\section{CASE STUDY EXPERIENCES WITH SHORT-ROTATION PLANTATIONS}

Short-rotation plantations are characterized by the establishment of hardwood species; planted at relatively dense spacings (2,000 to 10,000 trees/ha); closely tended like an agricultural crop with the control of weeds and pests and the management of nutrients; and harvested on a 2 to 12 year rotation. ${ }^{8}$ However, the minimum requirements for successful commercialization are economically and biologically rigorous. These minimum requirements include good land, fastgrowing plant materials, technical expertise, and experience. The requirement for experience is not to be taken lightly, as it is critical to understanding and dealing with all of the challenges associated with establishing and maintaining short-rotation plantations.

Before discussing the technical and economic aspects of short-rotation wood plantations, this chapter presents three actual case studies - the Philippines, Hawaii, and Brazil. The inclusion of these case studies not only provides background information on the technical requirments for short-rotation forestry, but also highlights the importance of experience. For each case study, issues related to plantation management including establishment, maintenance, protection, growth and yield, harvesting, and wood transport are discussed. Chapters that follow will refer back to these case studies as needed and present addtional experiences as relevant.

\section{PHILIPPINES CASE STUDY}

In 1979, the Philippine government, recognizing the increased demand for fuelwood generated by a growing population, and hoping to substitute wood for imported fuel in some industrial processes, initiated programs aimed at developing and managing plantations for woodenergy. The government efforts favored action-oriented programs over those demanding extensive preliminary research - over 60,000 ha in energy crops were planted. Planners recognized that mistakes would occur, but believed that corrections could be made as programs evolved. Significant problems did emerge and the Philippine experience offers important insights into factors influencing the success of programs to support wood-energy plantation development.

Various government agencies at the federal level implemented programs encouraging the development of energy plantations. These included the National Electrification Administration (NEA), the Farm Systems Development Corporation (FSDC), the Ministry of Human Settlement (MHS), and the Bureau of Forest Development (BFD). Programs established ambitious goals and were wellfunded. Provincial, municipal and village plantations were attempted as well, although few successful plantations developed under local government programs. Private corporations and individuals also established tree plantations for fuelwood in areas where markets were dependable.

Programs differed in target audiences (which ranged from small farmers to corporations), level of financial and technical support provided, and intended energy markets. For example, the NEA's Dendro Thermal Power Program used wood to generate electric power for rural power grids, the FSDC's program produced wood for conversion to charcoal, and the NEA's TANGLAW Program produced wood for a variety of purposes with the marketing strategy dependent upon the location of the plantation.

While BFD programs are the largest in terms of acreage, the Dendro Program has been more extensively documented. The Dendro Program anticipated the development of 60 to 70 woodfired electric powerplants that would be supported by multiple energy crop plantations of 1,100 ha or more. Wood to supply the powerplants would be grown by upland farmers recruited by the NEA rural electric cooperatives that would manage the projects locally. Farmers were organized into 
associations of 10 families each. Support to farmers included: leases of government land at concessionary rates, loans to defray the costs of plantation establishment and management, technical assistance, infrastructure development, guaranteed markets, and health and medical benefits.

A report on the Dendro program covering the period 1980 to 1984 indicates that while planting success improved over time, tree survival and plantation cost effectiveness varied dramatically. Of 44 project sites, 13 had not yet established 100 ha of plantations, and five sites had sunival rates below $10 \%$. However, six sites had established more than 400 ha of plantation and nine sites had survival rates above $80 \%$. Managers attributed this success to site suitability and secure land tenure. Managers suggested the following as contributors to failures: unfavorable soil conditions, free-roaming cattle, inadequate institutional support and poor organization, and the discontinuation of the farmer loan program. Plantations developed under private initiatives noted above were often more successful than government projects. Reasons reported include the establishment of plantations on better quality land and the provision of more protection to young plantations.

\section{Plantation Management}

Site Selection. While procedures for plantation establishment vary throughout the Philippines with climatic, edaphic, social, and economic variations, commonalities may be discerned. The high population density of the Philippines means that there is a high demand for land in lowland areas with quality soils. Energy plantations and associated forestry production activities are usually relegated to roadless sites that are steep, rocky, and infertile. Surveys of NEA and FSDC energy plantation sites indicate that planting frequently occurs on 40 to 60 degree slopes, and soils with a $\mathrm{pH}$ below 5.0 predominate in some areas. The dry season at many project sites lasts 5 to 7 months. The lack of roads and trails at mountain sites complicates seedling distribution, silviculture activities, and marketing. Most of the land developed under NEA, FSDC and MHS programs was previously under BFD management. The BFD has been accused of refusing to relinquish the better lands under its control. In some areas, political forces have determined the location of plantations; these sites have generally produced poor results.

Species Selection. One species, the giant ipil-ipil (Leucaena leucocephala), represents more than $90 \%$ of the total area planted. While the tree grows rapidly, fixes nitrogen in the soil, is easy to manage, coppices readily after harvesting, produces excellent fuelwood and leaves that provide high protein livestock feed, it grows poorly at altitudes above $500 \mathrm{~m}$ or in soils with a pH below 5.5. Use of ipil-ipil in inappropriate settings has in some instances been disasterous. One Dendro Project site lost 1,021 of 1,031 ha planted. Efforts to diversify the species used are now underway.

\section{Plantation Establishment, Tending and Protection}

Plantations are usually established on areas of grass or brush, although secondary forests are occasionally converted. Clearing, therefore, can usually be accomplished without chain saws or heavy equipment. Competing vegetation is removed by slashing with machetes followed by burning. Virtually all tree planting is done by hand. The recommended spacing is $1 \mathrm{~m} \times 1 \mathrm{~m}(10,000$ trees/ha). Although container grown seedlings have the highest survival rates, direct seeding is more common. With favorable soil and water conditions, direct seeding can be as successful as planting seedlings. In some cases, direct seeding results in overstocked stands because farmers tend to plant several seeds at each planting mound. Overstocked stands mean few stems grow to 
desired diameters. Little thinning occurs for various reasons. Some managers fear thinning would lead to overcutting, while some farmers feel that returns would not offset associated labor costs. In many places, upland crops are planted along with (or before) seedlings and harvested before the tree canopy closes. Cultivating crops tends to lead to more effective suppression of competing weeds and grasses and more active protection of trees from fire and livestock. Plowing is expensive and most slopes are too steep or rocky to permit its use.

Plantations require weeding frequently until the trees reach a height of 1.5 to $2.0 \mathrm{~m}$ or until the canopy begins to close. At least three weedings at two month intervals are necessary before trees overtake grasses. Grasses and weeds are typically cut by hand and placed at the base of young trees for mulch. Upon reaching $2 \mathrm{~m}$ in height, little maintenance is required. Plantations may be checked two to three times a week to guard against livestock, fires and illegal woodcutters. Fertilizer is not commonly applied because of its high cost. Serious psyllid infestations have been encountered in many leucaena plantations; however, farmers are reluctant to invest in insecticides to protect trees. While most trees survive, growth may be severely curtailed.

\section{Growth, Production, and Harvest}

Growth rates of energy plantations vary greatly, depending on the quality of the site and plantation management. The NEA plantations experienced annual growth rates that range from less than $20 \mathrm{~m}^{3}$ ( 8 tonnes)/ha to $90 \mathrm{~m}^{3}$ (36 tonnes)/ha. ${ }^{10}$ Annual growth averages $40 \mathrm{~m}^{3}$ to $60 \mathrm{~m}^{3}$ (16-24 tonnes)/ha. Under average conditions, trees used for charcoal or firewood are harvested after 3 years. Subsequent coppice crops may be harvested after 2 years. Plantations producing fuel for dendrothermal powerplants have been harvested at 3 to 5 years. At this point the trees have a diameter at breast height of 5 to $13 \mathrm{~cm}$. Coppice crops reach harvestable size in 2 to 4 years.

Harvesting and transport are difficult and expensive. At harvest, most energy crop plantations are clear cut 15 to $25 \mathrm{~cm}$ above the ground. Small branches and tops are trimmed and left in the field. Harvesting is done with chain saws, machetes or both. In some cases, harvesting with chain saws has been abandoned in favor of machetes. Unfamiliarity, fuel costs, and maintenance problems are identified as reasons. A 1981 study by the International Labor Organization found that handtools were cost competitive with small chain saws. Harvesting production rates vary with equipment, topography, and the skill, strength, and stamina of operators and laborers. At the Panalco I site, individual laborers harvest $1.5 \mathrm{~m}^{3}(600 \mathrm{~kg})$ on average each day using machetes. At Casureco IV, workers with chain saws fell about $30 \mathrm{~m}^{3}$ each day. Trees are trimmed and stacked by other workers. Daily wages for wood cutters reflect prevailing rates for unskilled labor. Chain saw operators are considered semiskilled and receive a wage premium. The pakayao method (pay for work performed) is applied at most sites.

Forwarding wood from the point of harvest to loading stations is a significant challenge because of rugged topography and the lack of roads and trails. Initial plans called for the use of motor driven skylines at a number of plantations. Twenty winch systems were purchased at a per unit cost of approximately $\$ 27,000$. However, Durst found that the feeder winches system was still in use at only one plantation. Experience at Casureco, the plantation continuing the use of the winches, indicates that considerable time and skill are required for setup, the winches are not easily transported to rugged roadless areas, and fuel and maintenance costs are significant. ${ }^{11}$ Mono-cable systems have also been criticized for their high investment cost. Most forwarding is therefore done by manual labor, workers carry or skid logs down slopes without animal or mechanical assistance. The process is difficult, time consuming and dangerous. Proposals to aid in the problem of forwarding logs include suggestions for hand winches, low-cost motor driven swing winches, 
skidding using water buffalo, water buffalo powered cable yarding, and slides constructed of polyethylene pipe. Water buffalo are practical only where slopes are not steep or unstable. Trucking is the primary means of transporting wood to markets with truck size and type determined by road quality. Trucks are loaded and unloaded manually.

\section{Observations}

Significant problems were encountered in the Philippine wood-energy programs in the 1980 's. Many plantations failed and overall the Philippine program would be judged to have been unsuccessful. For plantations that survive, yields and incomes are often less than expected. Factors contributing to the failure of these programs include actual yields that fell short of forecast yields, problems related to the difficulty and cost of forwarding and transport, irregularities in the administration of project funds, and, in some areas, problems related to peace and security. Additional problems are specifically related to the biomass powerplant projects. These include power plant design deficiencies (particularly related to fuel preparation and handling), and contracted wood suppliers who sold wood to other markets.

Durst suggests that additional research into problem areas is needed for future program viability. ${ }^{12}$ Such research would include: alternative native species; the economic effect of plantation stock density (maximized biomass vs. increased planting, tending and production costs); optimal tree size at harvest; alternate forwarding and transport mechanisms; effects of repeated biomass harvest on soil fertility; and opportunities for improved project analysis (by adjusting market prices for distortions due to taxes, subsidies, trade restrictions, etc.).

Today the Philippine Department of Environment and Natural Resources (DENR) is attempting to attract the private sector to plant trees on open and denuded government lands. Affordable long term leases are offered on substantial areas (up to $40,000 \mathrm{ha}$ ), on the condition that trees are planted on a specified area within a specified period of time.

Although groups in the Philippines have generally shown little interest for renewed efforts to produce electricity from biomass, one private sector group is currently working toward the development and operation of $10 \mathrm{MW}$ electric powerplants fueled by biomass. Fuel supply is considered the most formidable hurdle. The plants would be fueled by wood chips and it is estimated that each $10 \mathrm{MW}$ plant would require approximately 155,000 tonnes of green wood chips annually. About 14,000 ha of marginal land would be needed to sustainably supply this fuel volume. The proponent proposes a five year crop rotation program, and desires a long-term fuel supply agreement with a supplier holding at least 30,000 ha under a DENR reforestation program. Fuel delivery would be the responsibility of the supplier. The proponent indicates that the key criteria in fuel supplier selection would be a track record in establishing and operating a tree plantation of at least 15,000 ha, and the financial resources to guarantee fuel supply. Potential fuel suppliers include logging companies, and pulp and paper mills. 


\section{HAWAII CASE STUDY ${ }^{13}$}

Hawaii's current dependence on petroleum as a source of energy, its distance from sources of fossil fuel, and its history of electric power generation from bagasse (residue from sugarcane processing) contribute to the appeal of energy crop production in Hawaii. In 1978, a joint research and development project to produce woody biomass for energy was initiated between BioEnergy Development Corporation and the U.S. Forest Service. The U.S. Department of Energy funded this effort for 10 years through its Short-Rotation Woody Crops Program. The project resulted in the establishment and management of 289 ha of eucalyptus tree farms.

\section{Plantation Management}

Site Selection. The Hawaii Department of Lands and Natural Resources inventoried lands within the state for their potential to support forestry activities. Two categories, prime 1 and prime 2 , are most suitable for intensive culture of Eucalyptus or other fast growing tree species. More than 243,000 ha are included in these categories. Of the 243,000 ha, approximately 93,000 ha now lie fallow or are in sugarcane, brush, range or pasture. Nearly all the remaining acreage is in forest. Although the bulk of lands suitable for growing short-rotation energy crops are located on the island of Hawaii, each major island has significant forest development potential.

Field trials were established in two areas on the island of Hawaii, along the east (Hamakua) coast and south coast (the Ka'u District) at elevations from 300 to $600 \mathrm{~m}$. The Hamakua sites receive 5080 to $6220 \mathrm{~mm}$ of rain each year; the soils are highly weathered silty clay loams developed on volcanic ash. The Ka'u sites receive 1020 to $2290 \mathrm{~mm}$ of rain each year with four or more dry months; the area has rocky, organic soils that have low nutrient retention capacity. Total soil nitrogen concentrations vary widely, in both areas. At each of the two major locations, eight different sites were chosen to represent variations in elevation, soil characteristics, topographic and climatic conditions. Land used included recently harvested caneland, abandoned caneland, ranch lands, wasteland, and forest land. ${ }^{14}$

Species Selection. Ten species trials were established between 1979 and 1984 . Thirty species in total, including 15 eucalyptus species and twelve nitrogen-fixing species, were screened. As a result of the trials, Eucalyptus saligna and $E$. grandis were used most extensively in the plantings. Albizia falcataria, a nitrogen-fixer was chosen for use in mixed plantings. A. falcataria performed well on wetter areas, but its performance in the dry sites at Ka'u was judged unsatisfactory. Additionally, the dense foliage of the species contributed to breakage or blowdown in high winds, which was a factor at certain test planting locations. Test plantings indicate that poorly to somewhat poorly drained soils produce low biomass, as do locations with shallow soils or soils that have experienced substantial erosion. Researchers concluded that fertilizer application was unlikely to increase productivity in these settings.

Plantation Establishment, Tending and Protection. Planting stock is raised in small containers (or dibble tubes) at a nursery. The approach is labor intensive because the size of the operation did not justify investment in a automated system. About 450,000 seedlings can be produced annually; 150,000 in each of three four month cycles. The dibble tubes have a volume of $65 \mathrm{~cm}^{3}$, and are filled with a 2:1 mix of vermiculite and peat moss. After seeding, racks of tubes (100 tubes/rack) are stored in a roofed shadehouse and watered by an automated sprinkler several times a day. Germination occurs in 5 to 7 days; thinning to one plant per tube is done at 3 to 4 weeks. At 4 to 6 weeks $(7.5$ to $10 \mathrm{~cm})$, seedlings are moved outside to harden off under full sunlight. At the nursery, rainfall is over $5000 \mathrm{~mm} /$ year and, therefore, it is not possible to harden 
(acclimatize) the seedlings by withholding water. Outplanting occurs 3.5 to 4.0 months after sowing when seedlings are 30 to $38 \mathrm{~cm}$ tall.

On abandoned caneland (which had been out of production for periods ranging from 3 months to 25 years) and wasteland, a low ground-pressure tractor equipped with wide gauge shoes is used to pull a heavy-duty off-set cutaway harrow. On very rocky soils, a heavy roller is used to crush vegetation. In areas with particularly heavy vegetation and brush (e.g., those that had been abandoned for many years), a tractor equipped with a bulldozer blade is used to knock down brush so that the harrow or roller can then be used. Vegetation on cleared land is allowed to regrow 6 to 8 weeks. Similarly, volunteer cane on recently harvested caneland, is allowed to regrow for 6 to 8 weeks. At this point, the area to be planted is sprayed with a contact herbicide/pre-emergent herbicide mixture by a tractor drawn spray rig. However, the pre-emergent herbicide is ineffective and not used if the soil is mostly covered by mulch.

Seedlings are transported to the site in enclosed trucks or trailers to avoid wind exposure. Because of the small scale of operation, planting is done manually. A two person crew is used; one worker opens holes with a metal dibble or spade-like bar and the second worker places the seedling in the hole and compacts the soil around the hole. About 600 seedlings can be planted per personday at Hamakua sites. Planting in the rocky soils at Ka'u requires about twice as much time ( 300 seedlings per person-day).

Plantings generally receive two fertilizer applications and two herbicide applications within the first year. Fertilizer is applied at, or soon after, planting and also at six months following planting. A nitrogen, phosphorus, and potassium fertilizer (14-14-14) is used. Subsequently, only nitrogen is needed at most sites. Experiments with mixed plantings of Eucalyptus and Albizia falcataria, a nitrogen fixer, showed that at some sites it is possible to eliminate nitrogen applications beyond the first year by establishing appropriate admixtures of these two species.

The first herbicide treatment is provided 2 to 3 months after planting; the second application is performed only where needed at 5 to 6 months. Manual backpack sprayers are used. Additional herbicide applications may be needed with larger tree spacings as crown closure occurs later, however, the larger spacings also allow the use of mechanized mowing to control competing plants. Special care is required to avoid spraying the seedlings with herbicides because the young foliage is extremely susceptible to herbicide damage.

\section{Growth, Production, and Harvest}

The spacing of trees in short-rotation plantations affects individual tree growth rates, stand productivity, plantation management cost, and harvest costs. Higher planting densities have higher wood production rates in early years, but, in addition to higher planting costs, an associated decrease in the growth rate of individual trees results in higher harvesting costs. Although stands planted at densities of $1.5 \mathrm{~m}^{2}$ and $3.0 \mathrm{~m}^{2} /$ tree had the highest biomass production, the trees were small and, on average, did not attain the minimum acceptable diameter for cost effective harvesting $(15 \mathrm{~cm})$. Increasing growing space had little effect on tree height in the first two years, but resulted in substantially taller trees in later years. Tree diameter growth was even more strongly affected by increased spacing than was tree height. At an age of 6 years, trees planted with $12 \mathrm{~m}^{2}$ of growing space weighed 2.5 times as much as trees with $3 \mathrm{~m}^{2}$ of space. On a per hectare basis, however, the wider spacing produced only three-fourths as much biomass by age 6 . 
The accelerating growth of trees (age 5-6 years) that are planted at larger spacings is an important consideration in decisions on rotation length, especially if tree size is a significant factor in the cost of harvesting or in product value. In some cases, the productivity difference between spacing treatments begins to close rapidly in plantings of this age both in terms of total biomass and mean annual biomass. At the Chin Chuck test planting, for example, trees planted with $12 \mathrm{~m}^{2}$ of growing space are adding biomass at the rate 45 to $50 \mathrm{~kg} /$ tree annually, while trees at a $4 \mathrm{~m}^{2}$ spacing are growing at about $15 \mathrm{~kg} / \mathrm{tree}$.

Studies on the research plantings have defined the "operating" maximum diameter density line the maximum number of trees (tree density) that can be grown to a given mean stand diameter without incurring levels of competition that result in a significant number of dead or unusable trees. Researchers concluded that to achieve a minimum acceptable mean stand d.b.h. (diameter breast height; approximately $1.4 \mathrm{~m}$ above the ground) of $15 \mathrm{~cm}$ at 5 years, the initial spacing should allow at least $6.7 \mathrm{~m}^{2}$ of space per tree.

Factors, other than growth patterns, affect plantation management and decisions on issues such as rotation length. Some of these factors, which include product requirements, nutritional effects, environmental impacts (e.g., soil loss), and economic factors, are discussed briefly below. Product requirements in the use of biomass as fuel do not place significant constraints on rotation length as the total biomass is usable. In the production of high quality pulp, however, leaves, bark, and limbs are removed. As bark and foliage increase as a percent of total biomass as rotation length decreases, the use of a crop as pulpwood would favor longer rotation periods. Shorter rotation cycles have the disadvantage of removing more nutrients from a site. Longer rotations effect nutrient drain in two ways: nutrients are removed from the site less frequently, and on a per unit biomass basis lower levels of nutrients are removed. This is the case because Eucalypts appear to have efficient internal nutrient cycling mechanisms, and, consequently, larger trees have lower average nutrient levels than do smaller trees. ${ }^{15}$ With regard to soil erosion, longer rotations in energy crop production reduce the potential for erosion because harvesting, which would be performed by clear cutting, is less frequent. However, compared to current agricultural practice in many areas suited for Eucalyptus culture, the potential for soil erosion with tree farms would be low. Sugar plantations on the Hamakua coast currently harvest to bare soil on a two year cycle, and soil loss can equal or exceed 2.5 to $5 \mathrm{~cm} /$ cycle.

Harvesting is the single largest cost item in short-rotation tree crops. In limited harvesting trials in Hawaii, felling, chipping and hauling represented more than $50 \%$ of total wood chip delivery costs. Harvest experience indicates that logistics and tree size are major determinants of harvesting costs. Harvesting systems that allow equipment to operate near full capacity will be important in covering equipment costs. The development of smaller, less expensive harvest equipment that is more suited to the requirements of harvesting small diameter trees would also help reduce costs. Studies indicate that during harvest, tracked equipment caused less damage to tree stumps and soils than did wheeled equipment. Conventional logging equipment that was designed for larger trees handled the research trees without difficulty, but the felling heads caused extensive damage to stumps and this contributed to unsatisfactory coppicing.

Based on information available to date, researchers in Hawaii believe that three short-rotation management regimes for Eucalyptus are particularly promising. The first regime consists of pure Eucalyptus stands under the shortest rotation ( 5 years) to yield a minimum acceptable tree size (15 $\mathrm{cm}$ d.b.h.). This is achieved with trees planted at a density of $6.5 \mathrm{~m}^{2}$ and regular fertilizer applications during the rotation cycle. Total biomass yield at harvest is estimated at $100 \mathrm{dry}$ tonnes/ha (or 20 dry tonnes/ha/annual productivity). The second regime also consists of pure Eucalyptus stands, but tree spacing, rotation cycle, and final tree diameter breast high are greater 
(11 $\mathrm{m}^{2}, 6$ years, $20 \mathrm{~cm}$ d.b.h.). As with Regime No. 1, regular fertilizer applications are required during the rotation cycle. Total biomass yield is estimated at 112 dry tonnes/ha or $18.6 \mathrm{dry}$ tonnes/ha/annually. The third regime is a mixed planting of Eucalyptus and Albizia. The Eucalypts and Albizia are planted in alternating rows $3 \mathrm{~m}$ apart. Within rows, Eucalypts are spaced $3 \mathrm{~m}$ apart; Albizia plants are spaced $2.1 \mathrm{~m}$ apart. In an eight year rotation without the application of fertilizer after the first year, this regime produced Eucalypts with a $23 \mathrm{~cm}$ d.b.h. and Albizia with a $11.4 \mathrm{~cm}$ d.b.h. Biomass yield, excluding Albizia, is estimated at 180 dry tonnes/per ha or 22.4 dry tonnes/ha/annually. Including Albizia, total biomass yield is estimated at 235 dry tonnes/ha or more than 29 dry tonnes/ha/each year.

\section{Observations}

The Hawaii case study is extensive with many significant results, which are applicable to locations throughout the world. However, despite the results and high growth attained, the competitiveness of plantation biomass for energy is not favorable. The price of competing fuels, coal and oil, at present represent significant challenges to the development of biomass for fuel on a larger scale. Australian coal can be delivered to Hawaii at a price of just under $\$ 60 /$ tonne. Given the relative heat contents of biomass and coal, biomass needs to be produced, harvested, and transported at costs under $\$ 40 / d r y$ tonne. Another obstacle to the commercial production of plantation hardwoods has been the inability of any group to obtain large tracks of land of 12,000 ha or more. In late 1994 this obstacle was removed by the sale of the Hamakue Sugar Company land to Bishop Estates and agreement with the state to gain access to an adjacent $2000 \mathrm{ha}$. Bishop Estates anticipates establishing plantations on the land but final use of the wood has not been determined. ${ }^{16}$

\section{BRAZIL CASE STUDY ${ }^{17}$}

Although Brazil represents half the land area of South America, its reserves of oil and coal are relatively small. Further, Brazilian coal is high in sulfur and ash and of relatively low quality. Brazil's search for alternative energy sources began with the passage of the Forest Code of 1965 and Public Law 5106 in 1966 . These laws implemented incentive programs that affected the forest products sector and, as a result, the area of planted forest increased from 470,000 ha before incentives to 6.5 million ha in the 1993. A major fraction of the charcoal used in steel production and nearly all of the feedstocks used in the pulp and paper industry are now derived from these plantations. Eucalyptus plantations represent $51 \%$ of the planted forest area; the genus Pinus accounts for an additional $32 \%$ of plantings. A native species, bracatinga (Mimosa scabrella), is also used extensively in wood energy plantations in southern Brazil. The scale of short-rotation forest plantations in Brazil dwarfs the experience in other countries. Nonetheless, these plantations provide only $39 \%$ of the wood used for industrial purposes in Brazil.

Fiscal incentives were important factors in the development of a pulp and paper industry and a charcoal-based iron and steel industry in Brazil. The cement and composite board industries are also large consumers of plantation grown wood products. The growth of the pulp and paper industry, however, was probably the single most significant factor that promoted the development of large-scale eucalypt plantations in the 1970s. Brazil has become a net exporter of short-rotation based wood products including pulp and paper, plywood, hardboard, and pine lumber. Forest products production accounts for $5.6 \%$ of Brazil's Gross Domestic Product (GDP), $4 \%$ of Brazilian exports and approximately 2.5 million jobs in rural areas. 
Another dimension of Brazil's experience with plantation forestry is the growing importance of farm forestry, including intercropping (agroforestry) of trees and food crops. ${ }^{18}$ Today farm forestry accounts for as much as $20 \%$ of the total plantation area, with some forestry companies expecting to raise this fraction to $50 \%$. In the mid-1980s with the removal of federal tax incentives and objections by environmentalists to large-tract plantations, forestry companies began contracting with private farmers as a means to expand wood supplies. Typically, the forestry company provides the material (seedlings, fertilizers, herbicides) and technical know-how for establishing the trees on the farmer's land and contracts with the farmer to buy some or all of the first harvest for an agreed upon price that incorporates repayment for the initial inputs and services. Farmers are willing cooperators as the trees provide an additional source of income from a certain market, allow the productive use of marginal areas, stimulate cooperation with fellow farmers, and make available more wood for onfarm use. Forestry companies like farm forestry because capital requirements are lower (i.e., lower establishment costs), there are no direct tending or maintenance costs, and transport costs can be lowered because farms are usually within close proximity to mills.

\section{Plantation Management}

Site Selection. When incentives were first introduced, no ecological zoning and no comprehensive body of scientific work existed to aid in choosing the best species for each region and site. Plantations were established in savanna-like regions in the central-west and southeast primarily because of low land prices. Climatic conditions in these areas, low annual rainfall and a 5-7 month dry season, were inappropriate for Eucalyptus grandis and E. salingna. These conditions, in concert with the remoteness of sites from potential product users, resulted in some major failures. In some cases, plantations never became well established because of limited groundwater availability or the presence of subsurface gravel layers that roots were unable to penetrate. Today much greater attention is given to site characteristics including existing vegetation, slope, chemical and physical characteristics of the soil, availability of water and energy, and distance from consumers.

Although native forest ecosystems have in the past been cut and burned to establish "reforestation" plantations, plantations are no longer established in areas with native forest cover. Further, rising land prices in industrialized regions over the last decade, and regulations by some states have made it difficult for forest companies to expand plantations in areas near their existing mills. Thus, companies have begun to emphasize higher productivity through genetic improvement of trees and careful soil management. Most plantations today are established on abandoned or degraded agricultural lands or on land previously occupied by eucalypt stands. Companies also prefer land that is flat or gently rolling to land with steeper slopes.

Species Selection. The most widespread Eucalyptus species in Brazil is $E$. grandis. Others include $E$. salinga, $E$. urophylla, $E$. camaldulensis, and $E$. citriodora. Hybrids, particularly urophylla $X$ grandis, are showing very promising results in several parts of the country. The federal government, state governments, and forest product companies carry out active genetic improvement programs for these species. Controlled hybridization, cloning and micropropagation are used to achieve homogeneous stands that provide high productivity, natural resistance to pests and diseases, and uniform raw material. E. camaldulensis is the preferred agroforestry species because of its more vertical canopy, which leads to less shading of the food crop planted between tree rows. Beans are preferred crop to plant with the trees.

Bracatinga, a native nitrogen-fixing tree, is a key plantation species in the cold highlands of southern Brazil. Although bracatinga has lower yields than Eucalyptus, it is preferred by many 
farmers because it can be grown at a much lower cost than Eucalyptus, a large capital investment is not required, and there is no need for fertilization, tending and control of leaf-cutting ants. Stands are generally planted at a density approaching 20,000 seedlings/ha and later thinned to 3,000-4,000 seedlings/ha. On a seven-year rotation, Bracatinga yields about $13 \mathrm{~m}^{3} / \mathrm{ha}$ annually. By the time a bracatinga plantation is harvested, seeds have been naturally incorporated into the soils and there is no need for replanting. Bracatinga has been collected locally by provenances and, like Eucalyptus, is the subject of genetic improvement trials.

Plantation Establishment, Tending and Protection. Vegetative propagation using stool beds or tissue culture is used to produce clonal seedlings. Seedlings are grown in dibble tubes filled with vermiculite or a vermiculite, compost, ground charcoal mixture. The nursery process for Eucalyptus seedlings requires 70 to 80 days. Seedlings spend the first half of the nursery period under shade; the second half in the sun. Most planting is done by hand. Seedlings are watered immediately after planting, and again after about a week, if rainfall has been limited.

Slash burning to prepare sites is rare today although it was common in earlier plantation establishment efforts. In early operations, harrowing, plowing and furrowing was conducted without regard to slope or runoff direction. The result was an enormous amount of erosion. Such intensive agriculture-like preparation is now being abandoned in favor of minimal cultivation techniques that reduce soil and nutrient loss. This approach involves the use of herbicides followed by furrowing that follows the contours of the site.

Plantings for short-rotation coppicing stands generally have spacings of $3 \mathrm{~m} \times 3 \mathrm{~m}(1,100$ plants/ha) or $3 \mathrm{~m} \times 1.5 \mathrm{~m}$ (2200 plants/ha). Fiscal incentives initially favored denser plantations, but many early plantations, with densities of 5000 to 10,000 trees/ha, were failures because mortality was high, final diameter was small, and the percentage of bark to wood was too high. Brazilian experience indicates that the mean annual increment increases with wider spacings. Wider spacings also reduce wind damage, facilitate harvesting and weed control, and allow the intercropping of agricultural crops when desired. Today, spacing is adjusted to produce a tree of a specified diameter at harvest, given site quality, plant genetics and rotation period.

Because Eucalyptus is an efficient nutrient user, it ultimately contributes to nutrient depletion which must be corrected with fertilization. Short rotations cause more nutrient loss because nutrient uptake is higher in young Eucalyptus plants. Seedlings normally receive an initial fertilization of $120 \mathrm{~g}$ of NPK. Unlike early operations that applied a standard fertilizer formulation to sites indiscriminantly, companies today have specific formulations for each site, species, hybrid and clone.

In Eucalyptus plantations weed control is performed twice a year, and is considered critical until canopy closure occurs, usually after the first two years. Initially, Brazilian plantations used discing between rows, and hoeing within rows, to control weeds. Discing, however, contributed to erosion (since rows were usually oriented downslope) and also cut the surface roots of the trees, retarding growth and sometimes killing the tree. Today weeds are controlled by methods that do not disturb the ground surface, such as herbicides and mowing. Herbicides are applied just before planting and again at 4 to 8 months. Research has shown that sheep and cattle can also be used for the control of weeds, and that intercropping with agricultural crops can eliminate the need for tending operations during the first year.

Resistant clones, hybrids and species are used to control fungal diseases. The control of leaf-cutting ants is an expensive cultural treatment in Eucalyptus plantations. Leaf-cutters, once 
established, can destroy a young plantation in a few days. Consequently, plantations require careful monitoring to detect colonies at an early stage. The dodecachlor-based baits previously used to control ant populations were banned in 1992. A sulfluramid-based bait is now used.

Local insects, particularly the families Lepidoptera and Coleoptera, have caused problems for some eucalypts. Control was initially attempted via pesticides but environmental effects, growing insect resistance to pesticides and cost limited the effectiveness of this approach. The problem was partially alleviated through selection of species appropriate to sites and silvicultural practices such as pruning, but a major breakthrough occurred when the potential of biological controls was recognized. This is now the principle method of control used for insect problems. For example, many insects are controlled by encouraging the maintenance of local bird populations (by intermixing native vegetation with the eucalypts).

\section{Growth, Production, and Harvest}

Eucalyptus harvesting is becoming increasingly mechanized. The felling of trees is usually done manually with chain saws. An average operator cuts 120 trees/day. Crowns are lopped off; trees may be cut into sections or left whole depending on the equipment used to move trees to the landing. Loading is done with grapple loaders. Nearly $70 \%$ of transport to mills is done by truck; the remainder occurs by rail. The haul distance averages $70 \mathrm{~km}$ one way, with maximum hauls in the range of $200-300 \mathrm{~km}$. Transport fuel expense is a major concern to forest companies.

Bracatinga culture is an activity of smaller farms. Harvesting is generally done by axe. Logs are cut into 0.8 to $1.2 \mathrm{~m}$ lengths with a minimum $4 \mathrm{~cm}$ diameter. Horse carriers or tractor trucks transport logs to the roadside. Logs typically are sold from the roadside.

Productivity of short-rotation, large-scale Eucalyptus plantations in Brazil has increased dramatically over the past 2 decades. In some areas, annual yields rose from $35 \mathrm{~m}^{3} / \mathrm{ha}$ (16.5 dry tonnes/ha) in 1970 to $70 \mathrm{~m}^{3} / \mathrm{ha}$ (33 dry tonnes/ha) in $1993^{19}$. The increased productivity is the product of a substantial research effort, particularly in genetics and biotechnology, reinforced by better silviculture and management practices. Yields from farm forestry are somewhat lower, but establishment costs are lower as well.

Costs for one hectare of Eucalyptus on a seven-year rotation vary widely depending on the region, soil fertility, species, and technology. Logging and transport costs, for example, vary with region and terrain from $51 \%$ to $70 \%$ of total delivered wood costs. ${ }^{20}$ The planting and cultural costs of bracatinga are low and, consequently, logging and transport costs may reach $93 \%$ of total operational costs. ${ }^{21}$ Because most farm forests were planted only recently (late 1980s), harvesting is just beginning. Indications are, however, that delivered costs will be about the same as those from forest company operations.

After harvest, logging slash is burned or used for energy purposes. If coppicing is used for regeneration, the area may be disced and the site is broadcast fertilized. Stump sprouts normally appear within 2 to 3 weeks. If the stand is to be replanted, stumps are removed or are covered with soil, and seedlings are planted in the rows between stumps. In the 1970s and 1980s, declines were observed in the yield of Eucalyptus stands established by coppicing. Factors that contributed to the declines included the establishment of plantations on inappropriate sites, inappropriate provenances, large genetic variation in the seeds used, the incidence of canker, leaf cutter ant attacks on sprouts, and the damaging of stumps by harvesting. Most problems with coppicing have been solved and coppicing systems may be applied with reasonable success. Lower costs of coppicing (about $10 \%$ 
of planting costs) offset, at least in part, the reductions in coppice yields (reductions of approximately $15 \%$ for the first coppice and $30 \%$ for the second). Brazilian companies, however, are moving to the practice of renewing stands after the first harvest because the rapid improvement of genetic stock makes replanting a more cost-effective option.

\section{Observations}

Brazil's experience indicates that successful plantation establishment efforts have direct links to an existing or planned end user. Further, successful reforestation efforts require a fully funded government oversight organization and existing educational and research institutions.

Environmental groups in Brazil now exert considerable pressure to limit further eucalypt plantation establishment. Federal, state and municipal forest legislation is becoming more restrictive. Critics of monocultural Eucalyptus plantations claim that these plantings reduce biodiversity, encourage soil erosion, reduce soil nutrients, lower local water table levels and compete with the production of food crops. Reis proposed the following actions to minimize the environmental impact of Eucalyptus plantations: ${ }^{22}$

- Use ecological zoning to select species and appropriate management practices.

- $\quad$ Augment biodiversity through management that increases the use of agroforestry systems.

- Conduct research on ecological systems of native forest species that may substitute for Eucalyptus.

- Implement more biological, as opposed to pesticide based, pest control.

- Use less mechanized approaches on steep slopes.

- Institutionalize a process of environmental impact assessment.

The forest companies have responded by emphasizing forest management that is increasingly directed at the sustainable use of forest resources that include water, air quality, erosion control, wildlife, recreational and scenic values in addition to wood products. Many of the large forest product companies now have environmental departments to address environmental concems. The efforts of these companies include tree farmer programs in which small farmers are included in the forest company's supply planning and operations. These programs are expanding and will become more important supply sources in the future. Companies are also conducting research on agroforestry to provide the biological, technical and economic information needed to support such programs. Agroforestry programs, support of local education programs and donations made for the preservation of endangered ecosystems have enhanced the public image of forest product companies. These small farmer programs are also seen as a means to promote rural economic development, reduce migration to urban areas, and limit the growth in concentration of land ownership by forest companies.

There has always been intense public scrutiny of bracatinga use. Harvesting is permitted only for mature stands and only on a sustained yield basis. Widespread clearcutting of bracatinga is not allowed to reduce soil erosion and preserve water tables. The policy has contributed to a stabilization of fuelwood supply during a period of rising demand and, consequently to a rise in the real price of bracatinga. This has increased the income of thousands of small farmers. 


\section{THE PRODUCTION OF SHORT-ROTATION WOODY CROPS}

Eucalyptus species constitute about $38 \%$ of all short-rotation plantations worldwide and hardwoods in general make up about $63 \%$ of all plantations. In temperate regions, poplar, willow, and black locust predominate. Ranney estimates that about 10 million ha could be classified as short-rotation plantations. ${ }^{23}$ However, he notes that less than half of this planted area could be termed as successful or commercially viable. Ranney's technical criteria for successful plantations for energy use are described as follows (with slight modification):

- $\quad$ more than $80 \%$ survival of planted materials;

- annual productivity greater than 10-12 dry tonnes/ha of harvested wood and bark;

- uniformity in diameter, height and straightness;

- less than $\$ 50 /$ dry tonne in delivered cost;

- $\quad$ and less than 2 tonnes/ha in erosion each year.

This chapter discusses the factors to consider in site and species selection, plantation establishment, maintenance and protection as well as yield expectations to achieve the above measures of success. In addition, some of the distinctive aspects of producing trees on shortrotations versus practices used for producing timber in longer rotations will be addressed. More detailed technical information suitable for landowners or companies considering woody crop establishment may be located in some of the references provided in the notes to this chapter.

\section{SITE SELECTION}

It is often assumed that tropical countries have a major advantage over temperate regions with regard to biomass production, but this is not necessarily true. While total annual biomass production does increase from higher latitudes towards the equator, the increase is primarily in leaf production rather than wood production (Fig. 2.1). In general, the annual wood production of native tropical forests is slightly less than that of high latitude native forests. Reasons for the lower production rates of lowland tropical forests include acidic, highly leached soils and warm temperatures that increase respiration rates and burn off carbon that would otherwise be used to produce wood. Fortunately, well-managed plantations on good sites in tropical and temperate zones can achieve yields 2 to 10 times higher than natural forests. Examples of plantation yield levels currently being achieved around the world are summarized in Table 1.

At a global scale, soil fertility generally decreases toward the equator. At a regional scale there is variation in soil properties relevant to tree growth at.scales ranging from 10's of meters to entire continents. Any farmer or forester is familiar with variations in soil fertility that produce great differences in crop production across areas as small as a hectare. Factors such as soil depth, water availability, $\mathrm{pH}$, texture and slope are all extremely important to crop production potential. While naturally fertile soils are most desirable, there are instances where poorer soils can be managed. ${ }^{24}$ Soils with moderate limitations can be used, if technologies are available to manage the soils effectively. These lands with moderate limitations require careful planning and management to avoid problems related to erosion and water quality, and soil nutrient deficiencies. 


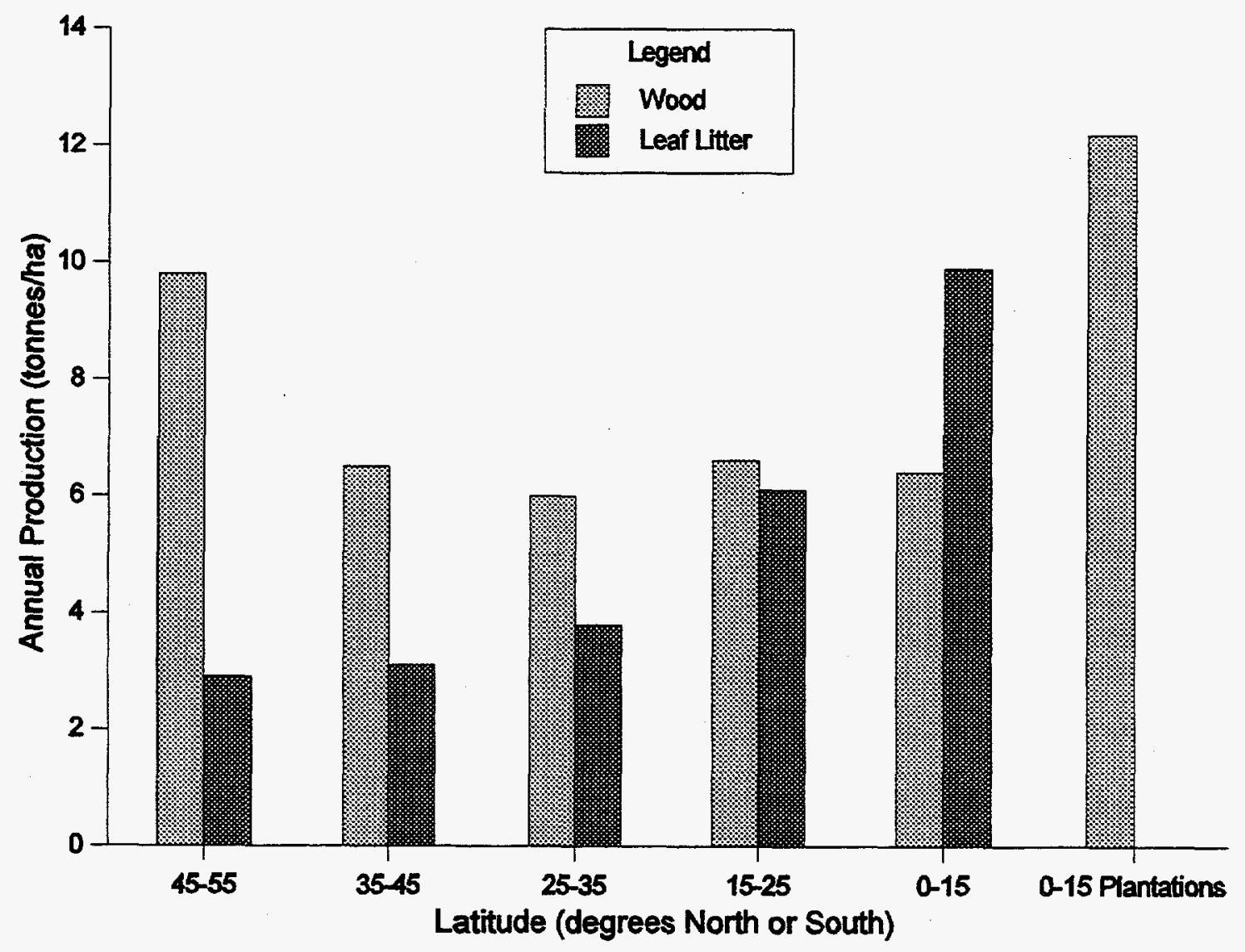

Fig. 2.1. Annual production of wood and leaf biomass of natural forests across a latitudinal gradient from the Boreal Zone to the Tropics. ${ }^{25}$ 
Table 2.1. Plantation biomass annual production rates from around the world

\begin{tabular}{ccccc}
\hline Species & $\begin{array}{c}\text { High } \\
\text { Yield }\end{array}$ & $\begin{array}{c}\text { Average } \\
\text { Yield }\end{array}$ & $\begin{array}{c}\text { Production } \\
\text { Region }\end{array}$ & References $^{26}$ \\
\cline { 2 - 5 } Poplar & 43 & $9-20$ & $\begin{array}{c}\text { Eastern US \& Pacific } \\
\text { Northwest }\end{array}$ & Wright, 1994 \\
Eucalyptus & 30 & $13-15$ & $\begin{array}{c}\text { NW Spain } \\
\text { SW Spain } \\
\text { Spain }\end{array}$ & San Miguel, 1988 \\
Eucalyptus & 21 & $5-8$ & Mid Brazil & Hall et al, 1993 \\
Eucalyptus & 27 & 12.5 & Hawaii & Whitesell et al, 1992 \\
Willow & 24 & $13-27$ & Northeast US & White, 1995 \\
Willow & 14 & $8-14$ & Sweden & Willebrand et.al 1993 \\
Willow & 23 & $13-23$ & Sweden & Christinson, 1987 \\
Eucalyptus & 28 & $3-21$ & NE Brazil & Carpentieri et al 1993 \\
\hline \hline
\end{tabular}

aYields increased by $30 \%$ to account for tops and branches.

bBased on small-plot trials.

One of the first challenges for any commercial activity requiring short-rotation plantations is to determine where suitable and available lands are located. A favorable site may allow a project to survive initial mistakes or miscalculations, while an unfavorable site requires great technical expertise, and even simple errors can result in major setbacks or failure. In site selection, there is no substitute for test plots of the potential tree species on the range of soils present on the prospective sites. A potentially disastrous consequence of over-estimation of yield is the under-estimation of planted area needed to support a power plant. With the increased plantation area needed on unfavorable, low productivity sites comes increasing expenses for road and harvesting infrastructure, increasing haul distances, less efficient harvesting, and greater potential impacts on the environment; society, and biodiversity.

Site selection must consider and balance a wide range of biological, economic, and societal factors. The biomass decision tree shown in Fig. 2.2 summarizes the information required and decisions that need to be made to determine whether a biomass plantation may be feasible. Site selection and planning at the national, regional, and local level requires geographically located information on soils and geology, natural vegetation, current land uses, topography, watershed boundaries, stream/river systems, roads, local political jurisdictions, land ownership and tenure information, location of cultural and historical resources, location of nature preserves and rare habitats and species. It is also very valuable to have site-specific research data on the yields that can be expected from the preferred species. The information is particularly helpful if it can be conveniently summarized, compared, and presented on maps using computer-based geographical information systems (GIS). The HNRIS database developed for the state of Hawaii is an excellent example of the type of data and GIS systems that is very valuable for making decisions regarding the best locations for biomass plantations. ${ }^{27}$ 


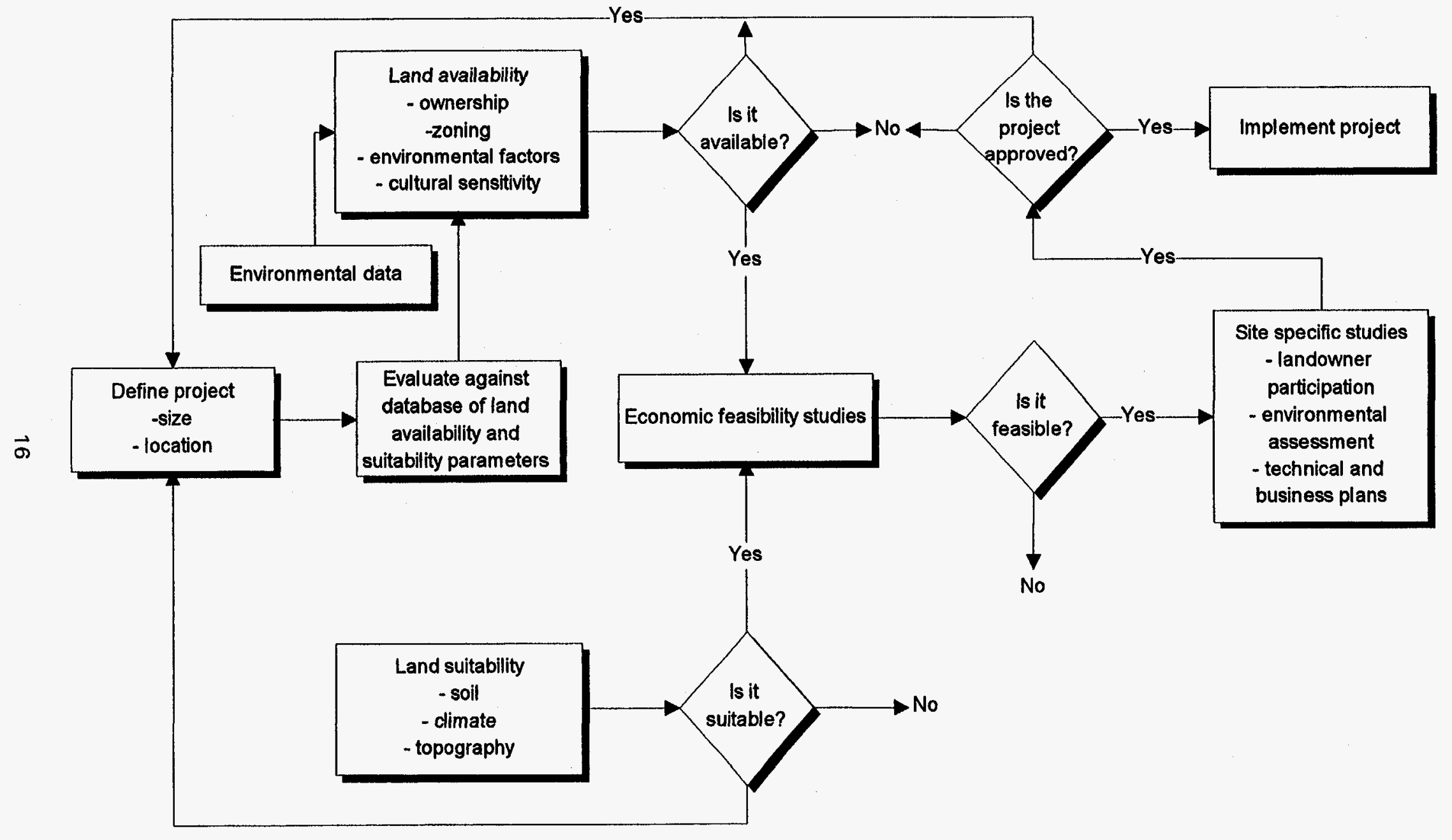

Fig. 2.2. Biomass project decision tree. ${ }^{28}$ 


\section{SPECIES SELECTION}

Once a site is chosen, the next key to the success of the plantation is the selection of genetically superior tree species, varieties or clones suitable for the climate, soils, and desired products of the plantation. Most species achieve their best growth under a fairly narrow range of climate and soil conditions, and failure to match species to site has been the cause of the failure of many plantation projects. Even within a species that is suited to a particular site, there can be great variation in the growth and wood characteristics from different seed sources or regions within the species range. "The largest, cheapest, and fastest gains in most tree improvement programs can be made by assuring the use of the proper species and seed sources within species". ${ }^{29}$ Many of the problems of plantation health, productivity, tree quality, and the economic viability of early plantation programs were the result of use of inappropriate species or clones and suboptimal plant materials. For example, Jari Cellulose S/A of Brazil is currently replacing all of the pines and gmelina planted on over 90,000 ha due to the poor growth.

Although indigenous species would be preferable from an environmental perspective, a large number of the plantations being successfully established in tropical regions are using exotics such as $E$. grandis and $P$. caribaea. Several acacia species, which are native to many tropical areas are showing good performance. In the U.S. and Europe, hybrid poplars and willows are, in most cases, outperforming native poplar species, although fast-growing native poplar clones have also been identified. The best hardwood species and clones for lumber and veneer are likely to be different than those that are best for energy or hardwood pulp.

In some temperate agricultural regions, herbaceous energy crops are being investigated. One advantage of such crops is that they can be planted and harvested using standard agricultural equipment rather than specialized forestry machinery. Perennial herbaceous crops, such as certain native prairie grasses, have the advantages of providing quick erosion control and wildlife habitat, quickly reaching full production, and providing continuous harvests without replanting. The best tropical analogy is sugar cane, although other tropical grasses or canes might have potential as well. ${ }^{30}$

Normal variation in topography, soils, and moisture conditions dictates that more than one species may be desirable to optimize sustainable production. While it may be desirable to use both grasses and trees as feedstock options from an environmental standpoint. Use of mixed tree species plantings would also provide more desirable habitat for wildlife than single species plantings. Where the conversion technology or product depends on feedstock uniformity, site differences can be partially compensated for by using many clones of the preferred species. Pulp companies such as Aracruz Celulose SIA in Brazil have developed a working set of 40 to 80 clones for taking advantage of small site differences, and attaining functional diversity for pest management and risk spreading

Nitrogen-fixing species, or fast-growing nurse species could be beneficial components of the overall species mix. Such species are likely to be particularly important where plantations are being established on degraded or abandoned agricultural lands though plantings would likely need to be subsidized since retums to the land owner may be limited due to low yields. In such cases, the initial species mix used to reclaim the site is likely to be different than the preferred species mix once the site has been improved by the initial rotations. Conversion technologies which can adjust to changing species composition over time will offer the greatest opportunity for producing environmentally sound, low-cost feedstocks. 
Species and clonal selections cannot be made exclusively from a study of literature. Unless a research program exists in the vicinity of a desired project, some trials of promising species will have to be part of the project development process. As described by Evans, these trials will normally be of four different types: ${ }^{31}$

- Step 1. Species screening and elimination trials to identify the most promising species.

- Step 2. Species refinement trials to examine genetic variation among provenances, families, and clones.

- Step 3. Larger production trials to provide stand growth data, test cultivation methods.

- Step 4. Tree improvement activities including breeding and clonal propagation.

This sequence takes time and often decisions are made after only step 1 . Steps 2 and 3 may be carried out while a project is being established and result in changes along the way. Step 4 is an ongoing commitment that is required once significant investment in a project has been made.

\section{PLANTATION ESTABLISHMENT, TENDING, AND PROTECTION}

Plantation establishment is a critical phase of a large-scale biomass energy project, since the timing of wood supply must be coordinated with the construction of a complex and expensive power plant. Mistakes or miscalculations at any one of many stages can result in expensive delays in power generation. Issues that must be addressed include: site preparation, seedling or cutting supply and quality, availability of required soil microorganisms, nursery operation, spacing of plantings, fertilization, watering, weed control, road construction, protection of nursery stock and plantings from insect pests, disease, animals, humans, fire, and other threats.

The particular properties of each plantation site and the species selected will affect how each of the above issues should be addressed.

\section{Site Preparation}

Site preparation is the key phase of establishing a short-rotation woody crop plantation. Site preparation on land not already used for cropping includes demarcation of boundaries, planning and construction of access roads, and installation of erosion control measures. While alteration of drainage to improve conditions for tree growth and minimize negative effects on the quality of water leaving the plantation may be needed, care should be taken that wetlands and or water quality regulations are properly addressed. The primary goal of site preparation is to create the best possible conditions for the growth of the tree species that will be planted. Site preparation requirements vary greatly among tree species and with variation in climate and soils. Most current recommendations suggest using land already cleared or planted in tree crops both for economic and environemental reasons. The most suitable sites for biomass plantations and the least expensive to prepare are lands recently or currently being used for agriculture. On many agricultural sites, ripping may be necessary to break-up hard pans that have devoloped over many years.

On recently abandoned agricultural lands, the main problem is often competition between planted seedlings or cuttings and pre-existing vegetation. Consequently, the goal of site preparation is to kill or remove as much as possible of the vegetation without degrading the site and creating erosion. For species that are extremely sensitive to competition from grasses, including most fastgrowing eucalypts, poplars and willows, complete kill of the competing vegetation is essential. Figure 2.3 indicates the strategies that may be required depending on existing vegetation. Both 


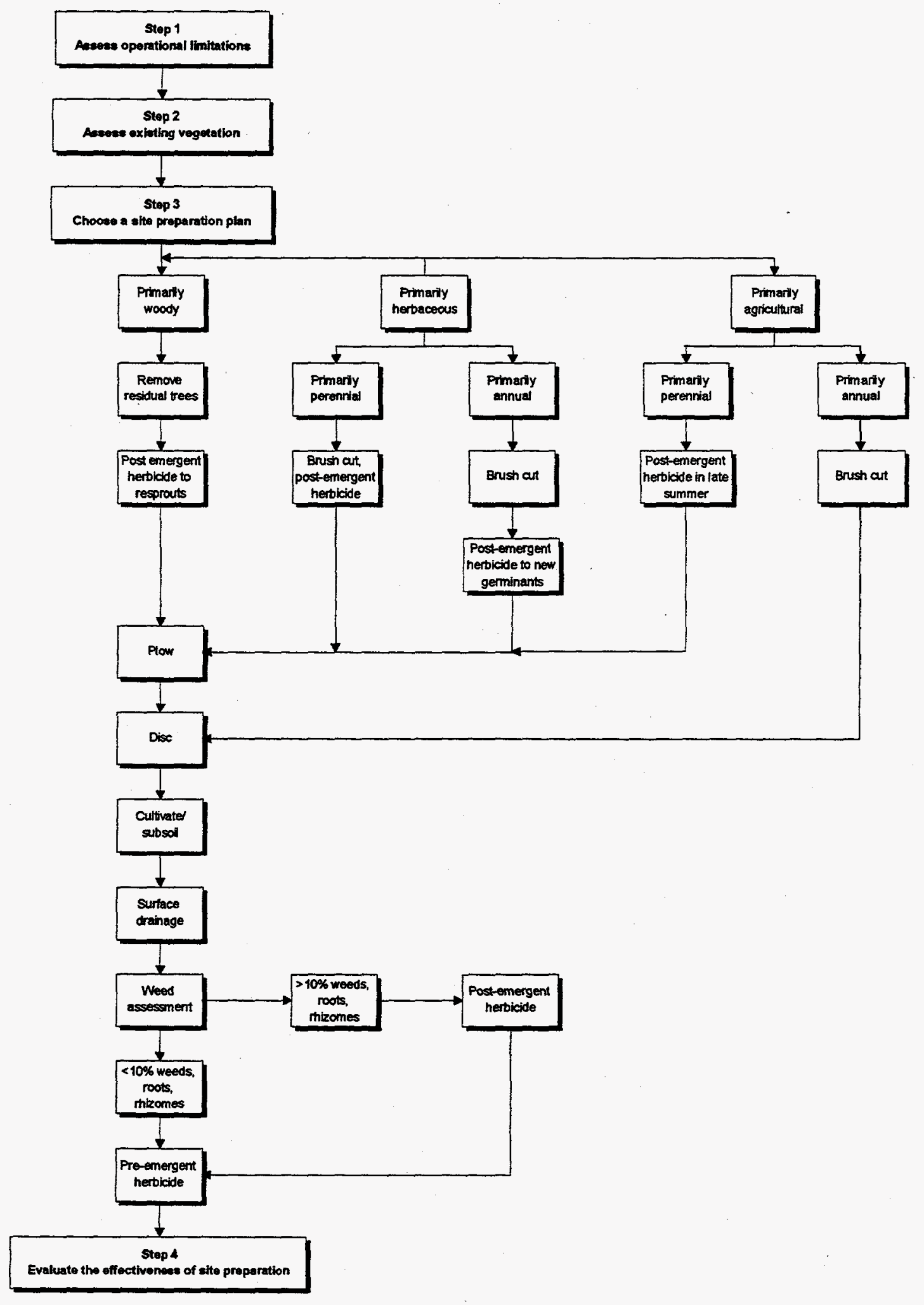

Fig. 2.3. Steps in a recommended site preparation strategy. ${ }^{31}$ 
herbicides and cultivation may be required if mowing is not sufficiant. This is particularly important in areas that have been invaded by aggressive grasses, such as Imperata cylindrica. Other species, including Acacia mangium, alder, and many pines, are tolerant of some competition from grass, and do not require such intensive site preparation, but also usually fail to produce high yields at a young age.

Experience in the U.S. suggests that site preparation should begin at least one full year in advance of planting short-rotation crops, if cultivation is required. Soil cultivation aids in reducing weeds, but also can be used to improve soil structure for root penetration in areas with compacted soil, impervious clay layers, or poor drainage. No-till site preparation may be appropriate if herbicides can be effectively used to achieve total grass and weed kill in strips where trees are to be planted. In some situations, clearing and burning may be appropriate, although this is usually ineffective for grasses because they have adapted to fire. Inadequate site preparation is the most common mistake made by companies and researchers initiating a new short-rotation woody crop project.

On severely degraded sites, competition with grass and weeds is less an issue than is the nutrient content and available moisture in the soil. Appropriate establishment methods may include leaving weeds, planting grasses in strips, applying organic matter, establishing a cover crop, and/or building berms or other structures to concentrate water.

\section{Seeds, Cuttings, and Nursery Operation}

Many first time plantings fail because high quality plant materials are scarce and poor quality planting materials are used. The materials may be too small, too big, diseased or too weak. Guidelines for optimal seedling and cutting size and handling requirements are available for the most commonly planted species. A common problem is that insufficient quantity of select material is available so the tendency is to use the poor quality material just to meet planting goals. Obtaining rapid growth early is so important for short-rotation systems that time and money should not be wasted on planting poor quality or unhealthy material.

Large centralized plant propagation and nursery operations that are owned by the power companies (or their subsidiaries) may be required for large-scale biomass power projects. Nursery operations are a standard component of most pulp and paper operations which depend on plantation grown wood. For smaller power project operations, it may be easier and more cost-effective to purchase seedlings or cuttings from commercial nurseries.

If plants are to be established from seed, the issues of seed availability, seed quality, seed storage, and germination requirements must be fully resolved in the project planning stage. The quality of seeds is particularly important, and success may depend on having a good supply not just of the desired species, but of the specific variety or provenance of that species that is best suited for the plantation site. To assure continuing supplies of improved high quality seeds, some investment in seed orchards and long-term breeding programs is necessary.

Most hardwood species receiving serious consideration as biomass plantations species can be propagated without seeds, from cuttings of twigs and branches that can be induced to grow roots, from root sections or branches that can be placed directly into the ground, or from tissue culture and micropropagation methods. A major advantage of vegetative propagation is that the individual trees that have the most desirable properties, disease resistance or rapid growth under specific local site conditions, can be rapidly multiplied as part of a tree improvement or clonal expansion program. Species vary greatly in their suitability for vegetative propagation, with some 
easily sprouting roots and leaves, and others only surviving under the most favorable conditions. Species that sprout and grow readily include: many Eucalyptus and Populus species, Acacia cyanophylla, Azadiracta indica, Cassia siamea, Chlorophora excelsa, Cordia alliodora, Dalbergia sissoo, Gmelina arborea, Leucaena leucocephala, Nauclea diderichii, Paraserianthes falcataria, Pterocarpus spp., Triplochiton scleroxylon, and Tectona grandis.

Depending on whether the species being planted are most effectively established as bareroot seedlings, containerized stock, or hardwood cuttings, propagation and nursery procedures will be quite different. Larger-seeded species can be sown in large beds and root- pruned to produce bare-root stock for planting. Trees being clonally propagated require stool beds of clearly identified clones for generating cuttings. Sprouts species such as poplars and willows are then harvested from the stool beds, sectioned, graded for size, packed, and kept in cool temperatures until planting season. Eucalypts which are produced from small seeds or small cuttings and species produced through micro-propagation, require well-run seed or propagule handling, containerization, and hardening operations to produce adequate sized planting stock. In general, container grown plants have a higher survival rate, than bareroot seedlings or cuttings, particularly in drier areas. However, container grown plants may cost from $25 \%$ to $250 \%$ more to produce than bare-root seedlings or hardwood cuttings. In all nursery operations, particular attention must be paid to fertilization and the prevention and control of fungal diseases and insect pests, as well as plant size and root quality/quantity.

Many species may have unique properties and problems at the nursery stage. Consequently, the experience that has been gained around the world with particular species under specific climate conditions should be utilized in nursery design. Local practices that work perfectly well for some species may result in total failure with different species. When Shell international chose to establish a eucalyptus plantations in Chile, local builders failed to follow exact specifications from Shell staff with previous experience in South Africa. This resulted in major problems and loss of much of the planting stock in the first year of operation. Once the buildings were reconstructed according to specifications, propagation was successful. ${ }^{33}$

\section{Spacing}

A primary question during the planning phase is the spacing (or density). Planting density affects the total cost of planting stock, the rate at which the tree canopy closes, the growth form of the trees, the optimal rotation age and the size at optimal rotation or harvest age. While production of large saw logs is most effective at large spacings or in thinned stands, plantations for biomass or pulp generally use narrower spacings ranging from about $4 \times 4 \mathrm{~m}$ down to about $1 \times 0.5 \mathrm{~m} .{ }^{34}$ The tightest spacings are characteristic of willow plantings, which are cut after 1 year to generate many sprouts, thereafter being harvested on a 2 to 3 year schedule. The widest spacings are more characteristic of plantings where the trees are expected to reach a 15 to $20 \mathrm{~cm}$ diameter (d.b.h.) by harvest age.

Within a certain range, maximum short-rotation plantation yields are not particularly sensitive to spacing, if weeds are effectively controlled and the stand is allowed to grow. The spacing does, however, affect weed competition. Tight spacings minimize weed problems by closing canopy within the first year. Wider spacings require weed control for 2 to 3 years, however, weeds can be effectively controlled by cultivation, and herbicides. 


\section{Planting}

Planting techniques will vary depending on the type of material being planted and the terrain. Hand planting is probably the most common approach even in industrialized countries. Hand planting by an experienced crew can be nearly as fast as mechanized planting with fewer mistakes. Unrooted cuttings offer the greatest flexibility in choosing hand or machine planting methods. However, it is suggested that painting or marking tops of unrooted cuttings will ease planting efforts and ensure that the right side is planted up.

\section{Weed and Pest Control}

Weed competition can be severe in the establishment phase of plantations and most establishment methods involve some use of cultivation and herbicides. ${ }^{35}$ it is most important to eliminate weeds close to the trees. Cultivation is most effective if the spacing is square and wide enough to allow cultivation. Application of herbicides over the trees, prior to leaf out, may accomplish the control needed close to the trees. Mulching is another alternative. In countries where labor costs are low and chemical costs may be high, manual labor is likely to be used to reduce weed growth immediately around trees. Depending on the relative costs of labor, machinery, and chemicals, the most cost-effective weed control practices can differ greatly from one area to another.

Another weed control alternative is agroforestry in which manual labor is used to tend food crops grown between rows of trees for one to two years. ${ }^{36}$ This practice can provide both subsistence and cash crops to the local community, while accomplishing weed control without harmful chemicals. ${ }^{37}$ Because of the economic and environmental advantages shown by agroforestry experiments in Brazil, some forest companies are beginning to recommend agroforestry in their tree farmer programs. ${ }^{38}$

Insect and fungal pests tend to be most serious when plants are stressed by poor soils, crowding, or other unfavorable environmental conditions. Pests can spread rapidly and cause extensive damage in single species plantations. The incidence of pest problems and thus the need for toxic chemicals could be reduced by use of multispecies plantings, either intermixed or blocked, by selection of resistant species and clones, and by carefully matching species and clones to site conditions to minimize stress. A combination of biological and chemical controls of pests using the principles of integrated Pest Management (IPM) is usually much more effective and much less costly than large-scale pesticide application.

\section{Protection from Fires and Animals}

Fires are a major risk factor that must be considered in planning the layout of short-rotation woody crops. Separation of planting blocks with strips of natural vegetation may assist in reducing fire hazard as well as increase local biodiversity. The roads needed for harvest access and wood removal should be made wide enough to serve as fire breaks.

Large animals, such as deer and moose, can create problems by browsing the tender shoots of young plants. While solar-powered electric fences could be used for keeping out large animals, this would normally be too expensive for large-scale operations. It may simply be necessary to accept some level of damage and claim credit for game populations in the region. Hunting is considered to be the most effective means of protecting plantations from excessively large populations of browsing animals. ${ }^{39}$ 
Rabbits and rodents can damage or kill trees by gnawing the bark and girdling the base of the trees. There is little protection for such animals in well managed plantations with low weed cover, thus providing another rationale for good weed control. There are no other suitable methods for protecting plantations against small rodents. ${ }^{40}$

\section{Stand Renewal}

The initial planting strategy should include a plan for stand renewal after harvest. Most shortrotation species being planted or under evaluation offer the option of stand renewal through resprouting or coppice growth. Although it was originally conceived that plantations would use the natural coppicing ability of hardwood trees, researchers growing poplar in the U.S. and eucalypts in Brazil are now suggesting that planting new and higher-yielding clones after each harvest will increase production and more than offset the increased costs associated with stump removal and site reestablishment. Continuous introduction of new clones also reduces risks associated with the buildup of pests and diseases.

\section{SUMMARY}

As stated at the beginning of this section, the requirements for successful production of short-rotation woody crops are rigorous. Unless experienced personnel are available, a new project should include some learning time with smaller plantings before an aggressive planting schedule is initiated. The crop production techniques will likely vary at least slightly for every project and experimentation needs to be a part of any commercial activity. A new project must take into account harvest and handling, environmental, end-use and cost considerations, which are dicussed in the following chapters. 



\section{USE OF PLANTATION-GROWN BIOMASS FOR POWER GENERATION}

The conversion of wood energy feedstocks to energy beginning with harvesting and ending with export of power to the electric grid is depicted in Fig. 3.1. Post-harvest fuel preparation, transport, storage, and fuel preparation and handling are key steps linking fuel production with conversion. These process steps influence the efficiency of the conversion facility through feedstock quality (moisture content, size, uniformity) as well as overall system cost. Figure 3.1 also shows feedstock handling and long-term storage losses. These losses can be significant and must be accounted for in determining total feedstock requirements for the conversion facility. Harvest, transport, storage, and fuel preparation techniques and requirements are discussed in the following section. A second section provides a brief overview of conversion processes.

\section{HARVESTING, TRANSPORT, STORAGE, HANDLING AND FUEL PREPARATION}

Harvesting is a significant cost and a technical barrier to commercialization and use of plantation-grown biomass for power generation. In the industrialized countries, considerable efforts have been expended to develop equipment for harvesting plantation-grown trees. Results of studies conducted during the mid-1980s conclude that cost-effective harvesting requires equipment be appropriately sized and be able to cut and handle large numbers of relatively small diameter trees. Conventional forest harvesting equipment tends to be inappropriate because it is designed for single-stemmed severance of large trees. Such equipment is also high-powered and expensive relative to the value of plantation-grown trees.

Much of the work on harvesting systems in the industrialized countries has been based on the development of feller bunchers, often as attachments to standard tractors. These harvesters have three functions: severing or cutting, accumulating, and offloading. ${ }^{41}$ For example, the prototype Hyd-Mech FB-7 continuous feller-buncher uses two counter-rotating saws for severing. Accumulating arms push severed trees off into holding areas. Once the holding areas are filled ( 8 to 10 trees), the trees are dumped alongside and parallel to the feller buncher. Other equipment (forwarder, grapple skidder, or tractor with grapple) is then used to move the piled trees to a landing area. Here the trees can be chipped and blown directly into a trailer or van for transport or simply loaded in whole form and hauled to a conversion facility. In the latter situation, chipping or size reduction is done at the conversion facility.

Stokes and Hartsough analyzed the productivity and cost of three systems for harvesting a small diameter and large diameter plantation stand. ${ }^{42}$ Their analysis was based on studies conducted on $7.6 \mathrm{~cm}$ sycamore stand in south Alabama and a 10.2 to $15.2 \mathrm{~cm}$ eucalyptus stand in central California. The systems included a continuous feller-buncher, a three-wheel feller-buncher, and chainsaw harvesting. A grapple skidder or tractor with winch and a whole-tree chipper were also configured into a balanced harvesting system. Their results are displayed in Fig. 3.2. The first panel shows how tree diameter influences harvest system productivity. For the continuous fellerbuncher system, productivity was significantly higher when harvesting the larger diameter stands. In contrast, a chainsaw harvesting system was more efficient for the small diameter stand. The second panel shows a similar relationship - the continuous feller-buncher is more cost-effective for the larger diameter stands with chainsaw harvesting more cost-effective for small diameter stands. Although not specifically shown in Fig. 3.2, the Stokes and Hartsough data indicate that chainsaw felling is about 2.5 times more productive than the continuous feller-buncher for the small-diameter trees. However, bunching and skidding the cut trees to a landing greatly 


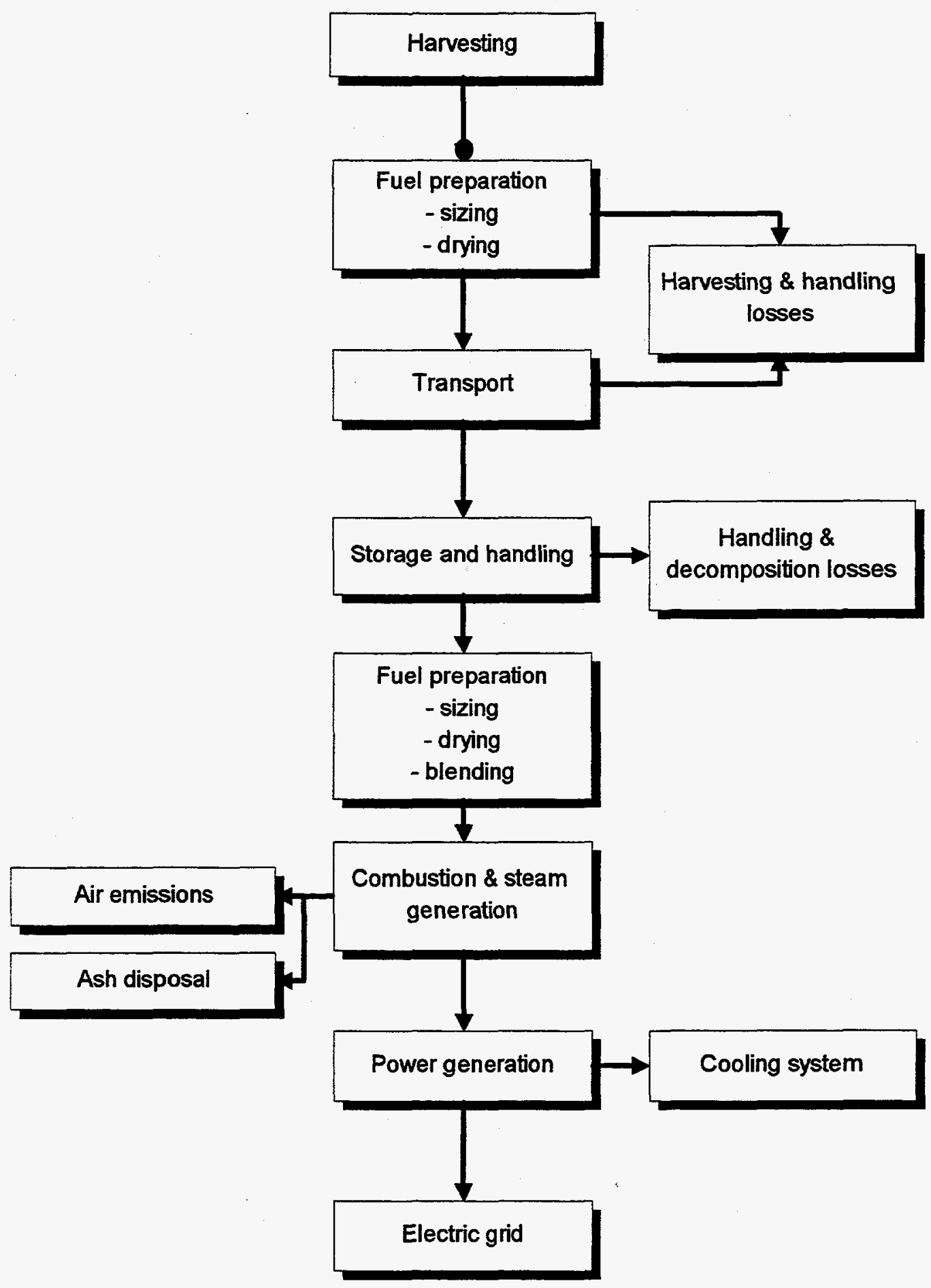

Fig. 3.1. Process diagram: plantation-grown biomass to power generation. 

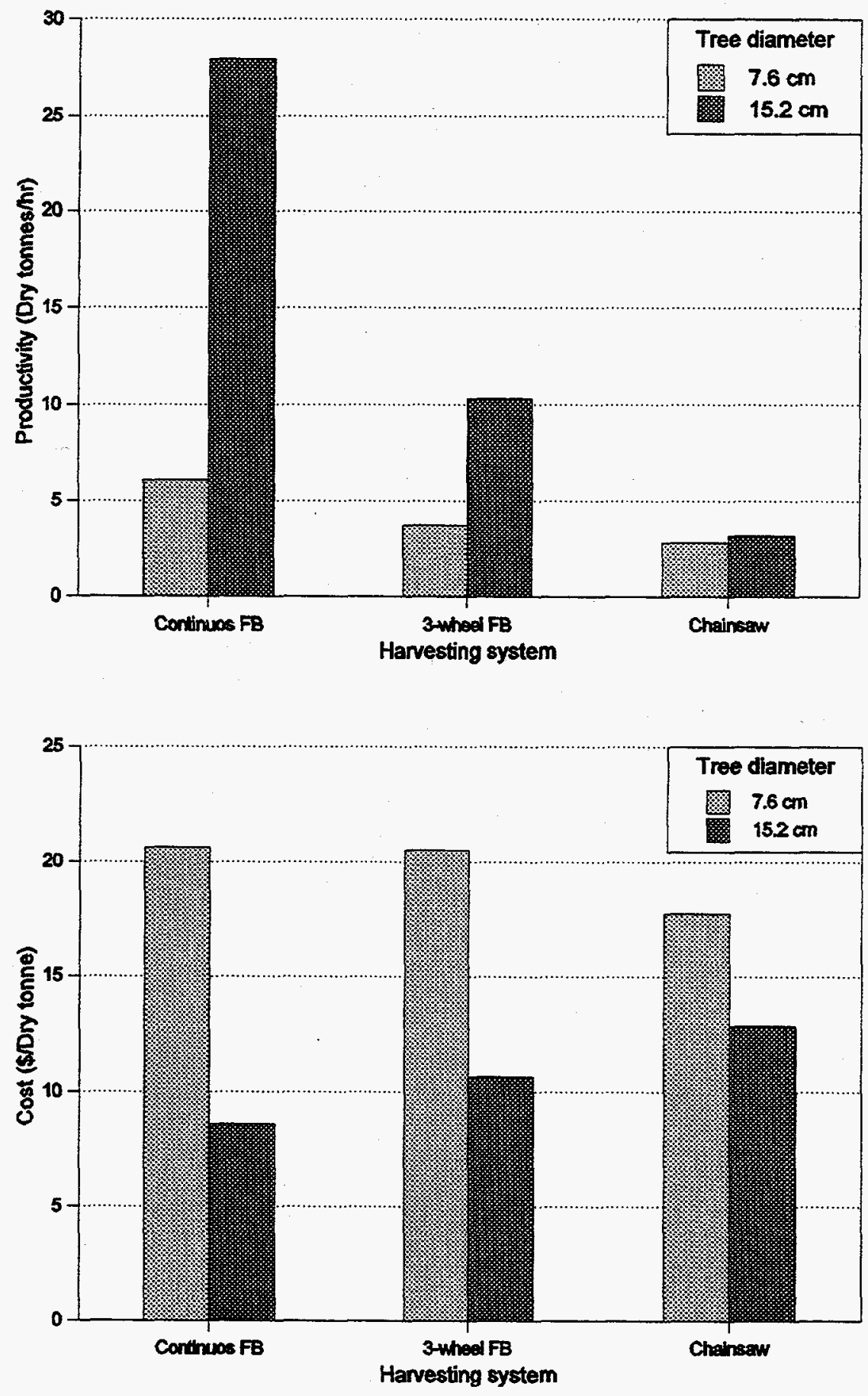

Fig. 3.2. A comparison of productivity and cost of harvesting systems for a large diameter $(15.2 \mathrm{~cm})$ and small diameter $(7.6 \mathrm{~cm})$ plantation stand ${ }^{43}$ 
diminishes the productivity of the chainsaw system. A comparison of the production rates achieved on other felling machines is shown in Table 3.1. These data also show a fundamental relationship between tree size (spacing or planting density) and productivity. A research team at the University of Hawaii (Manoa) has modeled this relationship and used it to identify optimum spacing and rotation age for short-rotation eucalyptus. ${ }^{44}$

The productivity and cost of plantation harvesting systems are quite variable. In industrialized or high-labor cost countries, estimated harvesting costs generally range from about $\$ 18$ to $\$ 35 /$ dry tonne for felling, skidding, and chipping. ${ }^{45}$ The low-end costs tend to presume the availability of prototype plantation harvesters while the high-end costs tend to be based on the use or modification of conventional forestry equipment. ${ }^{46}$ A large component of total harvesting system cost (about 30 to $40 \%$ ) is tree handling or skidding of bunched trees to a landing for chipping or loading.

In an effort to minimize handling operations, whole-tree energy ${ }^{\text {tm }}\left(W_{T E}{ }^{t m}\right)$ technology is under development. ${ }^{47}$ In the WTE ${ }^{m}$ system, trees are severed, accumulated, and loaded directly onto specially designed trailers for transport. This concept differs from conventional approaches in following respects. First, whole-tree harvesting eliminates tree skidding or forwarding, a major cost of plantation harvesting systems. Second, trees are not chipped or processed in the field. Instead, feedstock size reduction is done at the conversion plant. Third, the minimization of tree handling steps reduces significantly, if not eliminates, feedstock handling losses. Fourth, whole-tree harvesting equipment is optimized for single-stem severance (not coppice growth) and is utilized year-round. These factors have potential to reduce greatly harvesting costs. ${ }^{48}$ However, a WTE system as now envisioned is likely to be limited to sites that are relatively flat and accessible. Soil compaction is also a potential concern.

In contrast to the industrialized countries, where harvesting and handling operations have been focused on the development of dedicated plantation harvesting machinery, developing countries are basing their harvesting systems on the availability of low-cost and underutilized labor. In Brazil, most felling is done with chainsaws. A typical harvesting operation has chainsaw operators cutting three rows of trees at a time, directionally felling the trees so that they line-up. ${ }^{49}$ The trees are then crowned and cut to length or left whole for moving to a landing area. Production rates for an experienced chain saw operator can reach 120 trees/day. This is about $60 \mathrm{~m}^{3}$ or 28 dry tonne ( $0.47 \mathrm{dry}$ tonne per $\mathrm{m}^{3}$ ) per day ( $3.5 \mathrm{dry}$ tonnes/hour). After felling and cutting to length, grapple loaders are used to forward the logs to a landing for loading onto trucks (tractor-trailers) for transport to the conversion facility

For some applications, the availability of excess labor in rural areas, low wage rates, and scarcity of capital for equipment, maintenance and repairs, and fuel dictates that all harvesting operations (felling and forwarding) be done manually. For example, in Southwest China, Perlack et al. estimate that 75 workdays per hectare are required to fell, trim, carry, and stack logs at a roadside. ${ }^{50}$ Each hectare is assumed to yield 30 dry tonnes of wood energy at harvest excluding the smaller limbs and branches, which are left for nutrient recycling and fuelwood purposes. This production scenario implies a harvest rate of $0.4 \mathrm{dry}$ tonnes/day. In the Philippines, Durst estimated that over 130 days would be required to cut, top, and stack one hectare using handtools. ${ }^{51}$ This translates into a production rate of about 0.6 dry tonnes/day. A similar rate is provided by Denton, (100 kg/hour or $0.5 \mathrm{dry}$ tonnes/day assuming a 10 hour workday). ${ }^{52}$ In general, it is difficult to summarize production rates for manual harvesting operations because estimates are highly dependent upon local site conditions (topography, plantation density, tree size, forwarding 
Table 3.1. Productivity Summary of Machine and Manual Felling in Short Rotation, Biomass Plantations ${ }^{53}$

\begin{tabular}{|c|c|c|c|c|}
\hline Type of Machine & Species & $\begin{array}{l}\text { Average } \\
\text { diameter } \\
\text { (cm) }\end{array}$ & $\begin{array}{l}\text { Spacing (m) } \\
\text { (Trees/ha) }\end{array}$ & $\begin{array}{l}\text { Productivity } \\
\text { (Dry tonnes/hr) }\end{array}$ \\
\hline Hyd-Mech FB-7 ${ }^{a}$ & Sycamore & 6.3 & $\begin{array}{l}1.5 \times 3 \\
(1824)\end{array}$ & 8.7 \\
\hline Hydro-Ax 411 & $"$ & 4.3 & $"$ & 2.2 \\
\hline Hydro-Ax 411 & $"$ & 7.6 & $\begin{array}{l}1.8 \times 2.7 \\
(2017)\end{array}$ & 13.0 \\
\hline Morbark Mark V & Sycamore & 7.6 & $"$ & 5.3 \\
\hline $\begin{array}{l}\text { Chainsaw } \\
\text { w/felling frame }\end{array}$ & $"$ & 7.6 & $"$ & 5.1 \\
\hline Chainsaw & $"$ & 4.3 & $"$ & 1.3 \\
\hline VPI/DOE Harvester & Poplar & 8.0 & $\begin{array}{l}0.5 \times 0.9 \\
(21,607)\end{array}$ & 10.9 \\
\hline John Deere 493D & Cottonwood & 19.8 & $\begin{array}{c}3.9 \times 3.9 \\
(670)\end{array}$ & 26.2 \\
\hline Barko 775 & $"$ & 19.8 & $"$ & 45.4 \\
\hline UH Harvester & Eucalyptus & 7.0 & $\begin{array}{c}1 \times 1 \\
(10,116)\end{array}$ & 9.0 \\
\hline USFS Harvester & Poplar & 11.4 & $\begin{array}{c}2.4 \times 2.4 \\
(1700)\end{array}$ & 5.8 \\
\hline
\end{tabular}

${ }^{a}$ Productivity converted from green tonnes to dry tonnes assuming $50 \%$ moisture content. 
distances, climate, season, etc.). However, relative to capital intensive harvesting systems, costs are generally a smaller percentage of total delivered feedstock costs.

Harvest and handling operations will result in losses in product yield (Fig. 3.1). The significance of these losses depend on local factors including the degree of mechanization used in harvest operations. Some studies have conservatively assumed that felling, forwarding, and chipping operations can result in a $5 \%$ loss in the total standing dry weight yield. In manual harvesting operations, losses can be higher depending on how tree crowns and smaller limbs are treated. It is more likely that these smaller pieces are left on-site for use as fuelwood (plantation byproduct) and for nutrient recycling purposes.

When wood is harvested it normally contains about $50 \%$ moisture (wet basis). Moisture and other physical properties of wood should be taken into account when designing and operating woodfired power systems. The presence of moisture in wood can affect combustion by absorbing heat during evaporation; increasing the time it takes for wood to burn, and reducing the temperature of the combustion gases. Operational experience suggests that there can be significant decreases in boiler efficiency when moisture content begins to exceed $50 \%$. If feedstocks are allowed to air-dry to $30 \%$ moisture, there can be usable net heat gains. However, if the feedstock is allowed to absorb moisture during storage, a point can be reached where combustion can no longer be sustained. In this instance boiler blackouts can occur and auxiliary fuel will be needed to sustain combustion. Boilers specifically designed to handle high moisture content fuels do not have these problems, but they tend to be higher in cost. ${ }^{54}$ Moisture in wood feedstocks also creates problems in storing fuels for later use. These other problems include decomposition, self-heating, spontaneous combustion, and buildup of spores and moulds. ${ }^{55}$

Research on plantation-grown wood feedstocks in temperate climates has shown that harvest during the dormant growing season will be required to obtain good coppice regrowth. An added benefit is that leaves will be left on site to enhance nutrient recycling. ${ }^{56}$ Under such a scenario several months of storage is required to ensure a continuous supply of feedstock to the conversion facility. ${ }^{57}$ When feedstocks are stored for long periods decomposition losses can be high. Decomposition can be especially high under conditions of high humidity, rainfall, and evapotranspiration. How the feedstocks are stored (covered or uncovered) and in what physical form (chips or as bundles of whole-tree) also affects decomposition and the moisture content of the feedstock. Under less than ideal conditions, decomposition losses can easily reach $2 \%$ per month of storage. One option to avoid storage problems and decomposition losses is to harvest year-round. With year-round havesting crop decomposition losses do not occur as trees are in effect stored on the stump. This practice may not promote good regrowth and new stands may have to be established. Moreover, there may be periods during year, especially in tropical climates, where the plantation may not be accessible or roads not passable (e.g., during moonsoon periods).

There are numerous factors that must be considered in designing fuel storage facilities. These include:

- the available storage area and its proximity to the boiler;

- the physical properties of the fuel (chips, chunks, whole-trees, etc.);

- $\quad$ additional fuel preparation requirements;

- back-up storage capacity and reliability of the fuel supply;

- seasonal weather conditions; and

- $\quad$ operational requirements of the boiler. 
Fuel storage systems that are in use include both open and covered systems. For the open systems, the fuel is stored either directly on the ground or on a concrete pad. The covered systems can include plastic on slab (or on ground), open sheds, closed sheds, silos, and air bags. A typical operation is likely to include two types of storage facilities. An inactive area (open or covered on slab) where fuel is received and an active area (usually covered) that can store about 3 days supply. Front-end loaders and manual labor are most often used to move chipped wood feedstocks between inactive and active storage areas. The WTE ${ }^{\mathrm{tm}}$ technology uses a very large shed (air supported) to store and dry a 30-day supply of whole-trees using waste heat from the power plant.

Fuel-feed systems are used to transfer wood from the active storage area to the fuel hopper for metering and feeding into the boiler. This handling equipment can include various types of conveyors (belt, drag, screw, pneumatic) and elevators. Fuel hoppers are usually designed to avoid bridging and clogging (e.g., sloped walls) and they are covered to prevent sparks and smoke from escaping to the storage area. Screens and knife hogs or hammermills may also be used to remove unwanted material (e.g., rocks and debris) and to ensure appropriate particle sizes and uniformity. Uniform feedstock size helps to ensure more efficient fuel handling and combustion.

The characteristics and quality of biomass feedstocks greatly influences the design, choice, and performance of conversion technologies as well as the requirements for feedstock storage, fuel handling, and ash disposal. Biomass feedstocks that are variably sized and high in moisture or ash content can reduce boiler efficiencies, increase O\&M costs, and lower capacity factors.

There is a variety of equipment on the market that can be used for sizing. This equipment ranges from small-scale chippers that are towed or trailered to a site to large-scale equipment. The large-scale equipment can be mobile (trailered or self-propelled) or stationary. This equipment is usually configured with grapples for fuel feeding. Whether small- or large-scale, chips can be blown directly into a van or trailer for transport or piled at the conversion facility for storage.

There also exists a number of options regarding fuel preparation and handling systems. The wood feedstocks can be chipped "green" immediately after harvesting. Because many conversion systems are designed to bum green or high moisture materials $(<50 \%)$ and a variety of fuels, storing fuels to reduce the moisture content may not be necessary. Some conversion systems require that the feedstocks be dried significantly below $50 \%$ moisture. In this case, green chips would then have to be stored. Alternatively, felled trees can be stored in whole form (or chunks) for storage and drying. This practice would reduce decomposition losses. However, drier wood is more difficult to chip and to ensure uniform size.

\section{POWER GENERATION OPTIONS}

The use of plantation-grown biomass can be used for power generation in three general applications, these include:

- $\quad$ stand-alone, grid-connected biomass-based power plants using plantation grown feedstocks or mixed with agricultural residues;

- $\quad$ cogeneration at agricultural (e.g., sugar mills and rice mills) and forestry processing facilities for on-site heat and power needs with export of excess power to the local distribution grid using a combination of mill wastes (bagasse, rice hull, wood waste) and plantation-grown biomass;

- and co-firing at fossil-fired electric generation facilities. 
For each of these applications, the current conversion technology of choice is the steam-turbine cycle (Rankine cycle). The technology is relatively simple to operate and it can accept a wide variety of biomass fuels. However, at the scale appropriate for biomass, the technology is expensive and relatively inefficient when compared with fossil fuel power plants. ${ }^{58}$ As such, the technology is relegated to applications where there is a readily available supply of low-, zero-, or negative-cost feedstocks.

The low efficiency of biomass-fired power plants, relative to fossil-fuel plants, is due in part to the use of more moderate steam conditions. Biomass steam-turbine plants use lower pressures and temperatures because of the strong scale dependence of the unit capital cost $(\$ / \mathrm{kW}){ }^{59}$ Biomass plants can not be built at sufficiently large sizes to take advantage of scale economies (>300 MW $\mathrm{MW}_{\mathrm{e}}$ ) because the cost of supplying fuel to the plant would be excessive. Woody biomass has an energy density of slightly less than $20 \mathrm{GJ} / d r y$ tonne. When freshly cut, wood contains about $50 \%$ moisture. The high moisture effectively reduces the energy content of the wood by half. Relative to coal, a tonne of dry wood has about one-third less heat value than a tonne of coal. The high costs associated with handling, transporting, and storing large quantities of biomass effectively will this negate any scale economies associated with building large conversion facilities.

The remainder of this section examines several combustion technologies for biomass power generation. ${ }^{60}$ The technologies can be classified into currently available technologies that are in operation at the present time or capable of being in operation with minimal developmental barriers, and emerging technologies that are expected to require overcoming some technical barriers, before commercialization can be considered.

\section{Currently Available Technologies}

Conventional steam turbine systems. Except for differences in fuel handling and preparation and emissions control, wood-fired steam turbine power systems use essentially the same technology as that found in coal-fired plants. However, the lower density and heating value of wood relative to coal means that biomass systems require more combustion and heat transfer surface area. The tradeoff between additional costs of fuel handling and extra boiler combustion area for wood, and simpler emissions controls relative to coal translates into approximately the same installed costs $\left(\$ / \mathrm{kW}_{\mathrm{e}}\right)$ for biomass systems.

In a conventional biomass-fired combustion steam turbine, wood is first prepared (sized and possibly dried) then burned in a boiler to produce pressurized steam. The steam is expanded in a turbine to generate electricity. For power production, a fully condensing turbine is used. If process heat is to be produced in addition to electricity, a condensing-extraction (or back-pressure) turbine is used instead. In this cogeneration mode, some steam after producing electricity is taken from the turbine for process heat.

Specific boiler types used to generate steam include pile burners (dutch oven), grate burners (stationary or traveling grate), suspension burners, and atmospheric fluidized-bed combustors (bubbling-bed or circulating-bed). These combustion methods will produce boiler efficiencies ranging from 65 to $75 \%$ with net plant efficiencies from 20 to $25 \%$.

The most commonly used boilers for wood-fired systems are grate burners. The grates can be either stationary or traveling. Stollers are used to fuel wood into the boiler. For wood-fired systems, the spreader-stokes is most often used decause it can easily handle a wide variety of fuels. 
A second combustion design available for biomass are fluidized beds. In these designs wood (biomass) is injected into the combustion chamber through ports and burned in suspension. Air entering the boiler fluidizes a bed of hot, granular, inert material. The inert material heats the biomass quickly to ignition temperature, stores the thermal energy, and provides the appropriate residence time for full combustion.

Co-firing biomass feedstocks with coal. Co-firing plantation-grown biomass feedstocks with coal in existing utility steam boilers is a potentially useful process to reduce $\mathrm{SO}_{2}$ emissions. The addition of scrubbers to a coal-fired plant would sharply reduce $\mathrm{SO}_{2}$ emissions, but at a high cost. If only a moderate amount of $\mathrm{SO}_{2}$ emissions reduction is required, co-firing wood and coal can be a very cost effective alternative. Additions of new fuel handling equipment, modifications and improvements to boilers and electrostatic precipitators are required to co-fire with coal, but these changes would likely be less costly than installing scrubbers, switching to low sulfur coal, or purchasing emission allowances. Because of the moisture present in wood, some derating of the boiler may occur.

\section{Emerging Technologies}

The currently available biomass conversion technologies are relatively robust with minimal operating problems. ${ }^{61}$ However, a significant limitation of these technologies are low operating efficiencies that are due in part to the high moisture inherent in biomass feedstocks. One technology under development and testing that offers higher conversion efficiency is Whole Tree Energy (WTE ${ }^{m}$ ) technology. WTE ${ }^{\text {tm }}$ is an innovative steam turbine technology that uses an integral fuel drying process. ${ }^{62}$ Waste heat, preheated by the flue gas at $54^{\circ} \mathrm{C}$ is used to dry the wood stacked in a large, air-inflated building for 30 days before it is conveyed to a boiler and burned. Allowing the waste heat to dry the wet whole tree fuel can result in furnace efficiency approaching $87 \%$ with a net plant efficiency comparable to that of a modern coal-fired plant (35\%). WTE ${ }^{\text {tm }}$ also reduces wood harvesting and handling costs as well as the need for equipment such as hammer mills, screens, and chippers that are used for reducing the size of the wood feedstock. In the Lake States region of the U.S., busbar electricity costs from WTE ${ }^{\text {tm }}$ are projected to be about $\$ 0.043 / \mathrm{kWh}$ or about $\$ 0.015 / \mathrm{kWh}$ less than that of a coal-fired plant. ${ }^{63}$ WTE $^{\mathrm{tm}}$ can be built in sizes as small as $25 \mathrm{MW}_{\mathrm{e}}$; however, it is more likely that the market for this technology will be utility-scaled systems. Although there exists technical potential to increase the conversion efficiency of WTE ${ }^{\text {tm }}$ technology and other steam-turbine cycle systems, these developments are unlikely to be cost-effective. ${ }^{64}$

According to some experts the most promising technologies for wood-fired power generation lie in the development of gas turbine cycles. ${ }^{65}$ Gas turbines (or Brayton cycles) have already been developed for natural gas and clean liquid fuels. A key advantage of gas turbine technology is the potential for substantially reduced capital costs, which are relatively insensitive to scale, higher conversion efficiencies (upwards of $45 \%$ ), and greater modularity. Adapting the technology for biomass (i.e., Biomass-gasifier/gas turbine - BIG/GT) would require the use of a gasifier to thermochemically convert wood to a gas. The resultant gas would then be cooled and cleaned before being burned in a gas turbine. There are a number of technology choices for both the gasification and power generation portions of the BIG/GT cycle.

BIG/GT gasification. There are two principal gasification options for use with biomass or plantation-grown wood. These are the fixed-bed and fluidized-bed gasifiers. The most promising of the fixed-bed gasifier designs for biomass are updraft designs. In these gasifiers, wood is fed from the top of the gasifier undergoing drying, pyrolysis, and char gasification and combustion as it moves to the bottom of the gasifier. The gas is removed from the top side of the gasifier with air 
and steam injected into the bottom sides of the gasifier. Fixed-bed gasifiers are simple to operate and efficient when used with uniform and appropriately sized, high bulk density (e.g., wood chips) feedstocks. The most important technical issue associated with these gasifiers is hot-gas cleanup, primarily the removal of alkali compounds and particulates. Controlling the temperature of the gas and using cyclones for particulate removal can be used to provide a gas suitable for the turbines.

Relative to fixed-bed gasifiers, fluidized-bed gasifiers have greater throughput and can handle a greater variety of fuels including low-density materials such as agricultural wastes. This fuel flexibility characteristic may make fluidized-bed gasifiers the more appropriate choice for biomass applications. ${ }^{6}$ However, the resultant gas from fluidized beds is more problematic for gas cleaning. The exit gas has a temperature about $300^{\circ} \mathrm{C}$ higher than that for fixed-beds (500 to $600^{\circ} \mathrm{C}$ ). The higher gas temperature requires gas cooling to condense the alkali compounds. Particulate control is also likely to be more problematic and require the use of advanced filtering techniques.

BIG/GT turbine cycles. There are a number of alternative turbine cycles available and under development that can use clean fuel gas. In a simple-cycle configuration, fuel gas is burned in air pressurized by a compressor. The hot combustion gases are then used to drive a turbine. The exhaust gases from the turbine can be discharged (open cycle) or used in a heat recovery steam generator to raise steam for industrial or agricultural processing needs (cogeneration cycle). Because waste heat is used, the overall efficiency of the cogeneration cycle is higher than that of the simple cycle.

Both the open cycle and cogeneration cycle can generate electricity with an efficiency of about $32 \%$ (less than that from a modern, large-scale steam-turbine cycle). There are a number of cycles under development and/or demonstration that have the potential to increase significantly the efficiency of the power generation side of the cycle. One of these is the BIG/GT combined cycle ( $B / G / G T C C)$. This cycle is similar to the simple cycle except that steam from the heat recovery steam generator is used to generate additional power in a conventional steam turbine. ${ }^{67}$ About onethird of the total power output of a BIG/GTCC would come from the steam-turbine side of the combined cycle.

Steam injected gas turbine systems (BIG/STIG) are another option under development. In the BIG/STIG system waste steam from the heat recovery steam generator that is not needed for process uses is injected back into the gas turbine combustor, and at additional points along the flow path the gas is reheated to turbine inlet temperature, and then passed through the turbine. The additional steam mass injected into the turbine increases the total power output of the system and does not consume power at the turbine's compressor. Full steam injection allows the total system efficiency to approach $40 \%$. An advanced form of the STIG is the intercooled steam-injected gas turbine (ISTIG). This variation of the STIG can raise both thermal efficiency (from $47 \%$ to $50 \%$ ) and shaft power output.

In addition to gas turbines, fuel cells are also under development. Fuel cells convert energy produced by electrochemical oxidation of a fuel like biomass into electricity. The operation of a fuel cell has gaseous fuels being fed continuously to the fuel cell's negative electrode (anode), while oxygen or air (oxidant) is fed continuously to the positive electrode (cathode). A continuous electrochemical reaction occurs which produces an electrochemical potential or voltage and electric current similar to that of a conventional lead-acid battery. Several fuel cell types are currently under development. However, the phosphoric acid fuel cell (PAFC) is closest to commercialization. ${ }^{68}$ The 
PAFC fuel cell operates at approximately $390^{\circ} \mathrm{F}$ and has a cycle efficiency of as high as $45 \%$. Advanced fuel cell designs could reach efficiencies of about $57 \%$ by $2020 .{ }^{69}$

Biocrude oils can also be produced from wood using a pyrolysis process similar to that used in gasification. The wood feedstocks are thermochemically converted to a sulfur free mixture of biocrude oil vapors, non-condensible gases, water vapor, and char particles. The biocrude oil vapors are condensed to form a higher viscosity mixture of organic compounds with a heat value of $8,000 \mathrm{Btu} / \mathrm{lb}$. After the residual non-condensible gases exit the condenser, the gases are collected and burned as process heat for drying the feedstock or supplying heat to the reactor. Approximately $60 \%$ to $80 \%$ of the feedstock can be converted to biocrude. Biocrude can be used as a substitute for fuel oil for gas turbine cycles. Biocrude can also be co-fired with other fossil fuels. The pyrolysis process does not have to take place at the power generation site since the biocrude can be stored and transported. 



\section{ENVIRONMENTAL AND SOCIAL BENEFITS/COSTS OF BIOMASS PLANTATIONS}

Tree biomass plantations potentially offer many direct and indirect environmental benefits, but they may have negative environmental impacts as well. As recently discussed by Graham, ascertaining the environmental impacts are complex because the impacts of using biomass for energy must be considered in the context of alternative energy options while the impacts of producing energy crops must be considered in the context of alternative land uses. ${ }^{70}$

Globally significant environmental benefits may result from using wood for energy rather than fossil fuels. The greatest benefit is derived from substituting biomass energy for coal. ${ }^{71}$ The degree of benefit depends greatly on the efficiency with which the wood is converted to electricity. If the efficiency of conversion of wood to electricity is similar to coal conversion to electricity then the benefits are several. Airborne pollutants such as toxic heavy metals, ozone-forming chemicals, and releases of sulfur that contribute to acid rain will be reduced. The ash and waste products from burning will, in most cases, be sufficiently benign to return to the soil. There will be a considerable reduction in net carbon dioxide emissions that contribute to the greenhouse effect. For example, one dry tonne of wood will displace $15 \mathrm{GJ}$ of coal. The $15 \mathrm{GJ}$ of coal will have the equivalent of 0.37 tonnes of carbon assuming the wood is converted at an efficiency of $25 \%$ (Table 4.1).

Locally significant environmental benefits can be maximized when tree biomass plantations replace annual crops, heavily grazed pastures, or degraded lands. ${ }^{72}$ Benefits can include: (1) protection of water quality, (2) reduction of floods during wet seasons and maintenance of water supplies during dry seasons, (3) erosion prevention, (4) improvement of local microclimate through evaporative cooling and humidification, (5) wind breaks and shelters that reduce erosion and conserve water, particularly in dry regions, (6) reduction of fire danger, (7) reduction in use of fertilizer and agricultural chemicals, (8) improvement of soil properties, and (9) protection of wildlife and other components of biodiversity.

Negative environmental effects of plantations may occur locally if unmanaged natural forests or forests managed for low intensity uses are removed and replaced with short-rotation biomass plantations. Negative impacts can include: (1) increased erosion and reduction of water quality as a result of forest harvesting; (2) increased rates of runoff and decreased water-holding capacity; (3) increased chemical pollution from fertilizers and pesticides;(4) degradation of soil quality and productivity; and (5) reduction of biodiversity through alteration of forest structure, creation of tree monocultures, and use of non-native tree species which local wildlife are unable to use. $^{73}$ Concem over possible negative impacts has led environmental groups at both national and international levels to attempt to establish environmental guidelines prior to the commercialization of biomass energy technologies. ${ }^{74}$ In Brazil, early mistakes in establishment of Eucalyptus plantations, along with increasing environmental sensitivity, have led to substantial regulation of the forest industry. ${ }^{75}$

To minimize or avoid negative impacts from energy crop production, most proponents of biomass energy are recommending that biomass plantations be established on existing agricultural lands or degraded lands. ${ }^{76}$ Forestry codes and plantation management procedures currently being developed and implemented around the world generally prohibit the conversion of natural forest to forestry plantations. Many of the natural forests occur on relatively poor soils, and destruction of natural forests is now recognized to have environmental costs in terms of biodiversity, environmental 
Table 4.1. Example carbon offsets from short-rotation plantation energy used for power production and displacing coal

\begin{tabular}{lcc}
\hline \hline Factor & Wood & Coal \\
\hline Energy density (GJ/Dry tonne) & 19.8 & 29.3 \\
Heat rates (kJ/kWh) & $7,200-18,000$ & 10,900 \\
Feedstock carbon (kg C/GJ) & 50 & 70 \\
\% Carbon & 25.3 & 24.1 \\
Input carbon (kg C/GJ) & 1.34 & 0.53 \\
Total carbon (kg C/GJ) & 26.62 & 24.65 \\
1 dry tonne of wood displaces $370 \mathrm{~kg}$ of coal carbon (19.8GJ/tonne*10.9/14.4 MJ/kWh)*24.65 \\
\\
\hline \hline
\end{tabular}

Note: Feedstock carbon is the carbon embodied in the biomass or the carbon sequestered by plant growth. Input carbon is the carbon embodied in the factor inputs (e.g., diesel fuel) used to grow, harvest, and transport the biomass.

quality, and economic sustainability that far outweigh short-term economic gains from forest clearing. Principles recently formulated in the U.S. for the wise development of biomass resources include the following: ${ }^{77}$

- Biomass energy system development must be guided by consistent decision criteria and should foster the multiple goals of environmental protection, economic revitalization, and energy security.

- Energy crop production practices and energy conversion technologies must be selected to ensure that the use of biofuels substantially reduces anthropogenic emissions that may contribute to global climate change. The use of biofuels should not exacerbate greenhouse gas emissions when compared with conventional fuels on a full-fuel cycle basis.

- The development and management of biomass resources should protect and, wherever possible, enhance ecological integrity and biological diversity, while minimizing adverse impacts to land, air, and water.

- The development and management of biomass resources should contribute to the economic well being of producers, local communities, and the nation as a whole.

- The use of biomass resources for energy purposes must rationalize trade-offs in terms of competing uses for the land and plants (whether for food, fiber, recreation, wildlife habitat, or other uses), while also recognizing the impacts and trade-offs implicit in the use of other energy resources.

The remainder of this chapter provides more discussion of the effects of tree plantation on soils and water, biodiversity, chemical pollution, and social economics. 


\section{TREE PLANTATIONS AND SOILMATER ISSUES}

The beneficial effects of forests on water quality, soil erosion prevention, and the reliability of water supply have long been recognized. The oldest forest reserve in the Western Hemisphere was established in Trinidad and Tobago in 1765 with the designation "Reserved in Forest for the Rains," followed by further assessments in the 1880 s into "Forest Conservation and the Maintenance of Water Supplies." Many natural forest reserves have been established around the world in mountainous areas for the protection of municipal water supplies. Biomass plantations can also serve this purpose, particularly if the negative effects of harvest on soils and water supply can be minimized. Plantations are particularly valuable in improving the water supply on land that has been degraded by deforestation or desertification. ${ }^{78}$

The positive effects of plantations on soil and water conservation results primarily from protection of the soil surface from the direct impact of rain and from the improvement of soil structure through root penetration and the addition of organic matter from decomposing leaves, roots, and wood. In comparison to either crops or bare soil, forest greatly reduces the proportion of rainfall that is lost as runoff, thus leaving much more water available to feed springs and streams during dry periods (Fig. 4.1a). The positive effects of trees on water retention tend to increase over time, so long rotations and practices that enhance organic matter input into the soil are particularly favorable.

Tree species vary greatly in their effect on soil properties and on water cycling. Some tree species, such as $E$. globulus and $E$. tereticormis, tend to use water very rapidly, leading to reduced water yield from watersheds, stress during dry seasons, and creation of unfavorable conditions for interplanting with food crops. ${ }^{79}$ On the other hand, studies on Eucalyptus grandis in Brazil have found the annual variation in soil water to be similar to that for Pinus caribea and savanna-like native forests. ${ }^{80}$ Tree plantations have also been shown to reduce wind erosion, reduce evaporative losses of water, and improve soil moisture conditions sufficiently to allow cropping on degraded lands. ${ }^{81}$ Nitrogen-fixing species, such as acacias and leaucena, can improve the soil, reduce the need for expensive nitrogen fertilizer, and produce fodder for farm animals.

A primary difference between short rotation plantations, and forests harvested for timber with regard to erosion and water issues is the frequency of harvesting and replanting. Because $40 \%$ of tropical rainfall falls at erosive rates (greater than $25 \mathrm{~mm} / \mathrm{hr}$ ), soils exposed during and after harvesting are susceptible to serious erosion (Fig. 4.1b). ${ }^{82}$ Harvesting and reestablishment practices thus become a very important determinant of the potential for environmental damage. When reestablishment occurs through coppice resprouting, risk of soil loss is minimized by rapid regrowth. The use of cover crops or grass strips between the rows can reduce erosion when replanting is required.

The potential for soil loss increases greatly with increasing precipitation and on hilly or mountainous land (Fig. 4.1b). Harvesting with heavy equipment during rainy seasons is especially likely to cause serious soil erosion and soil compaction and may destroy the long-term productivity of a plantation. Due to both equipment constraints and erosion hazards, biomass plantations that are likely to be harvested every 5-10 years should not be located on steep, erodible soils. In general, tropical soils are much more subject to degradation from harvesting than forests on younger soils, such as those found in much of the temperate zone. ${ }^{83}$ 

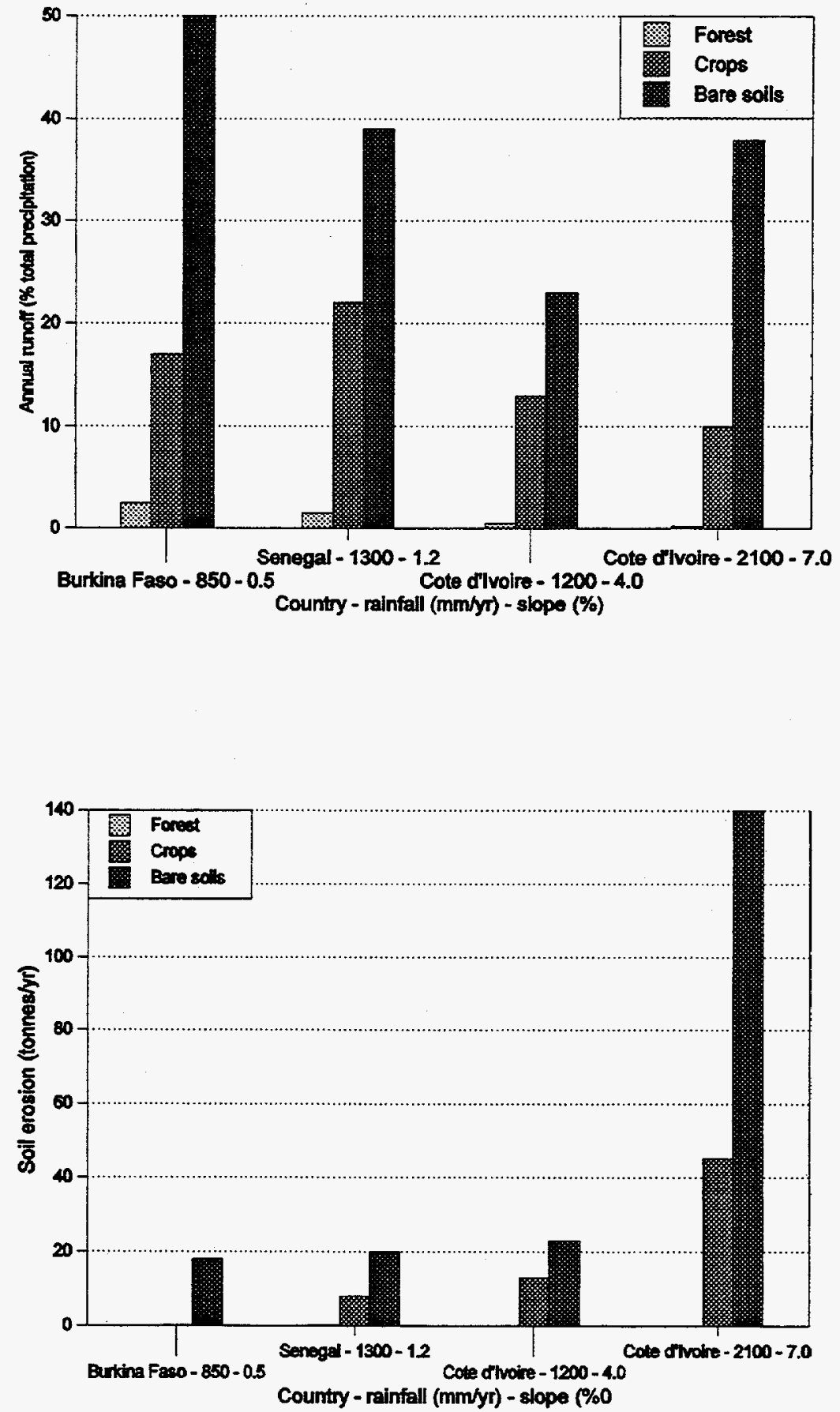

Fig. 4.1.a. and 4.1.b. Effects of land-cover type, precipitation, and slope on surface runoff and erosion at four tropical sites. ${ }^{83}$ 


\section{TREE PLANTATIONS AND BIODIVERSITY}

Biodiversity refers to the number of different kinds of plants and animals that are found in a particular area such as a hectare of forest, and entire country, or the earth. Concern about the loss of biodiversity is based on the idea that each organism, even those that are unknown and unnamed, has some value. Many plants and animals are valued for the medicinal chemicals they produce or for their importance to forestry or agriculture. Other species are valued for their beauty or other special properties. Many species, even obscure organisms in the soil, may play important but poorly understood roles in improving soil fertility, in preventing diseases and pests from affecting crops, or otherwise maintaining a balance of nature that is favorable to human existence. For these and many other reasons, there is a broad consensus among scientists, citizens, and politicians that biodiversity should be preserved by preventing the extinction of species wherever possible.

Because many birds, mammals, insects, and other animals depend on one to several particular tree species, extensive biomass plantations of a single tree species can be extremely destructive to biodiversity when displacing natural habitats. Clearing natural forests to establish plantations usually destroys biodiversity and should be avoided. Many of the forests with high biodiversity occur on soils that are too poor to support productive plantations, so there is usually no economically or biologically sound reason to replace them with plantations. Establishment of plantations on degraded lands that were previously deforested will usually have a positive effect on local biodiversity by improving the habitat for plants and animals that cannot survive deforested areas and may have other benefits such as improvement of water quality and quantity and soil improvement.

Tree plantations can be beneficial to biodiversity if properly designed or can be destructive of biodiversity when designed inappropriately. ${ }^{85}$ The effect of biomass plantations on biodiversity may depend as much on how they fit into the landscape as the particular species and management systems selected. Studies in the United States on hybrid poplar plantings have shown varied use by wildife, depending on the surrounding landscape. For example, plantations adjacent to natural forest seem to reduce "edge effects" and expand the usable areas for forest interior bird species in predominately agricultural areas.

There is considerable controversy on the use of non-native species on the scale that might be required for biomass energy. Plantations based on non-native species, such as eucalyptus outside of Australia and teak outside of Asia, are generally believed to provide little suitable habitat for native animals, ${ }^{86}$ although research on this issue is continuing. Depending on the planned energy conversion technology, plantations for biomass may be able to utilize a wider variety of tree species and thus may support a higher biodiversity of plants and animals than single-species hardwood or pulp plantations that must produce a crop that is extremely uniform in form and other properties.

Biomass plantations can have a positive effect on biodiversity if their design includes preserving areas of natural forest of different types within the overall plantation area. Research has shown that areas of natural forest included within plantations is favorable for many native species of plants and animals. ${ }^{87}$ Properly designed plantations should include areas of natural vegetation, appropriate wooded buffers for waterways and corridors for wildife movement, as well as protection of historical areas. ${ }^{88}$ Since the 1960 s Brazil has required forest companies to either leave $10 \%$ of the managed area in natural vegetation or ensure that $1 \%$ of the trees planted are native species. The $10 \%$ option has normally been preferred and has resulted in positive benefits for both bird diversity and insect pest control. ${ }^{89}$ 
Specific guidelines developed by the National Biofuels Roundtable in the United States for improving habitat are:

- Match native ecosystem cover types as much as possible (e.g., perennial grasses in prairie regions and trees in woodland regions). In addition, emulate natural vegetation patterns and functions when establishing energy crops on agricultural lands.

- Locate, plant, and harvest tracts of energy crops in ways that help improve pathways for animals to move between habitats and across landscapes in any particular year.

- Employ energy crops in ways that minimize the fragmentation of desirable habitats and improve overall habitat quality of the landscape for native species.

\section{TREE PLANTATIONS AND CHEMICAL POLLUTION}

The previous use of the land will determine the extent to which chemical pollution is an issue. Plantations generally require fewer inputs of fertilizers, herbicides, and pesticides than more intensive forms of agriculture..$^{90}$ In regions of extensive agricultural activity where non-point pollution of streams is a problem, tree plantations may improve water quality by serving as a filter of agricultural chemicals.

Establishment of plantations on pasture land, as may occur in many parts of the developing world, would result in additional use of some chemicals unless hand labor is used to control weeds. As described in Chapter 2, methods are available to minimize chemical use such as mulching and applying chemical only in strips around the trees though the relative costs of these measures have not been well established. Pest control can occur with minimal chemical use if frequent monitoring and biological control methods are used. The most effective method of pest control is to maintain ongoing breeding and genetic selection program so that susceptible trees can be eliminated and replaced with resistant varieties. Brazilian pulp and paper companies have been successful in controlling pest problems though genetic selection programs.

\section{TREE PLANTATIONS AND SOCIAL ECONOMICS}

Successful woody crops can provide multiple economic, social, and environmental benefits to a state, region, country if properly planned and integrated into the multiple landuse opportunities within the country. In regions where the amount of good quality soil is limited, use of the best soils for biomass crop production will displace other land uses. The concern expressed most often is that use of land to produce biomass crops will reduce food availability. Such a concern was expressed in the mid-eighties when sugarcane establishment was accelerating in the agricultural state of Săo Paulo, Brazil as a result of subsidies provided by the National Program for Alcohol production (commonly referred to as ProAlcool). The article entitled "Brazilian Alcohol: Food versus Fuel" by Rosillo-Calle and Hall describes the complexity of food production and export policies in Brazil as well as details on the sugar cane expansion. ${ }^{91}$ The food versus fuel controversy was exaggerated in their view. They conceded that the ProAlcool might be part of a larger overall problem which would best be described as a "commodity export crop production versus domestic food production" issue. With $64 \%$ of the sugar cane expansion in the state of São Paulo occurring on pasture land owned by large land-holders, displacement of primary food production was not the major issue.

Tree plantations always exist in a social and cultural setting based on the inhabitants of the area before the plantation was created, and the inhabitants who arrived after the plantation was 
established. To be economically successful, and to avoid negative effects on society and the natural environment, each plantation must be designed for its own specific social, cultural, and environmental setting. Factors that must be considered include (1) preexisting land uses; (2) local agricultural practices; (3) local political systems and hierarchies of authority; (4) local cultural divisions of labor and authority between men and women; (5) local traditions of land tenure and stewardship including private property right; and (6) local cultural values. ${ }^{92}$

Because plantations must depend on local labor, it is desirable to maintain the structure of the local community in a way that provides a steady supply of reliable workers. The more the plantation can be integrated into the daily economic and social life of the community, to the mutual benefit of both the community and the plantation, the more likely it is to succeed in the long run. For this reason, Brazil and China are leaders in investigation of agroforestry techniques for large scale use. Tree establishment can be enhanced, and the need for dangerous chemicals reduced, through the interplanting of agricultural crops during the first years after planting. This type of agroforestry benefits the plantation as well as the local community by providing food and/or cash crops.

The use of multipurpose trees that provide energy products, animal fodder, and enrich the soil through nitrogen fixation are viewed as the ideal energy tree..$^{93}$ It is likely this is the reason that leucaena was the species selected for use in the Philippine Dendrothermal program. Research has continued around the world on leucaena, acacias and other nitrogen fixing trees such as black locust. However, there has been an unfortunate tendency for these species to be susceptible to insect pests. Leucaena plantings have largely been destroyed by a psyllid pest and black locust is susceptible to a stem borer. These problems may be solved through genetic selection, biotechnology or biological control agents ,but at present, the widespread planting of nitrogen fixing trees for energy or pulp is not occurring. Even so, the multipurpose tree concept is a good one that deserves continued consideration. One success story is occurring in Brazil with a company that has a specialized conversion technology to produce pulp, alcohol, cattle feed and even electricity from a bamboo (Bambusa vulgaris) species. ${ }^{94}$

In summary, plantations for production of biomass energy have numerous potential environmental benefits. Conclusions from a roundtable of industry, academic, and government participants in the United States found that "if energy crops are included in the general mix of agricultural crops in a considered and informed way, environmental damage can be avoided; in fact, there could be significant environmental and ecological benefits achieved in tandem with the development of a fully sustainable energy resource. ${ }^{n 5}$ 



\section{ECONOMICS OF PLANTATION-GROWN FUELS FOR POWER GENERATION}

Feasibility studies tend to show that plantation-grown biomass to electricity projects can be financially viable provided local resource conditions are favorable and that the cost of conventional power supplies are expensive. Improving the competitiveness of plantation-grown fuels for power generation will require:

- lower cost and sustainable feedstock production systems,

- and more efficient and lower capital cost conversion technologies at scales appropriate for biomass energy applications.

This final chapter discusses the costs of producing plantation-grown biomass and the costs of generating electricity from these fuels.

\section{THE COSTS OF PRODUCING AND HARVESTING PLANTATION FUELS}

Key to producing low-cost plantation feedstocks is the land base and the quality of sites. The land base and the quality of sites determine to a significant extent the degree of site preparation necessary; the choice of species, spacings, and rotations (cutting cyoles); required cultural management and soil amendments (fertilization, weed control, animal control, and pest management); and fuel transport and logistics. ${ }^{96}$ Land and site quality also defines biomass productivity, the major determinant of total feedstock cost. Productivity is also a key factor in determining the total size of the plantation, annual feedstock production, and the size of the conversion facility that can be supported. Some of these land and site quality tradeoffs are illustrated in Fig 5.1. The right-hand portion in Fig. 5.1 shows how the total plantation area required to meet a given feedstock requirement is affected by productivity (dry tonnes/ha/yr). Greater plantation productivity directly translates into reduced land requirements. Alternatively, a given plantation land area will be capable of supporting more conversion facility capacity at higher levels of productivity. The left-hand panel shows a similar relationship with net plant efficiency. Higher conversion efficiency translates into more installed plant capacity for a given feedstock requirement or less required plantation area for a given installed capacity.

In North America and Europe, developers of short-rotation plantation forestry initially assumed that marginal cropland, poorly stocked forest land, and pasture would be the land base for growing energy crops. This focus gradually changed when it became apparent that there was excess and underutilized cropland not needed for food production, and plantation-grown feedstocks could be a potentially important alternative crop to conventional agriculture. ${ }^{97}$ Economic studies also showed that the use of good cropland for energy plantations was more cost-effective than using marginal cropland or poorly stocked forest land. The additional cost of the land was offset by lower establishment costs and, more importantly, higher biomass productivity. In addition, the use of cropland for energy plantations is thought to have positive environmental benefits in terms of reduced erosion and chemical use relative to the marginal row crop agriculture it would displace. And, in some locations, the use of cropland could improve habitat and biodiversity. ${ }^{98}$

In contrast, the land base for plantation-grown feedstocks in tropical, developing countries is primarily cleared and degraded forest lands, forest lands occupied by low-value commercial species or brush, marginal forest lands that have many physical limitations (e.g., poor soils, low rainfall, high elevations and steep slopes) and, possibly, non-forest land including extra-marginal 


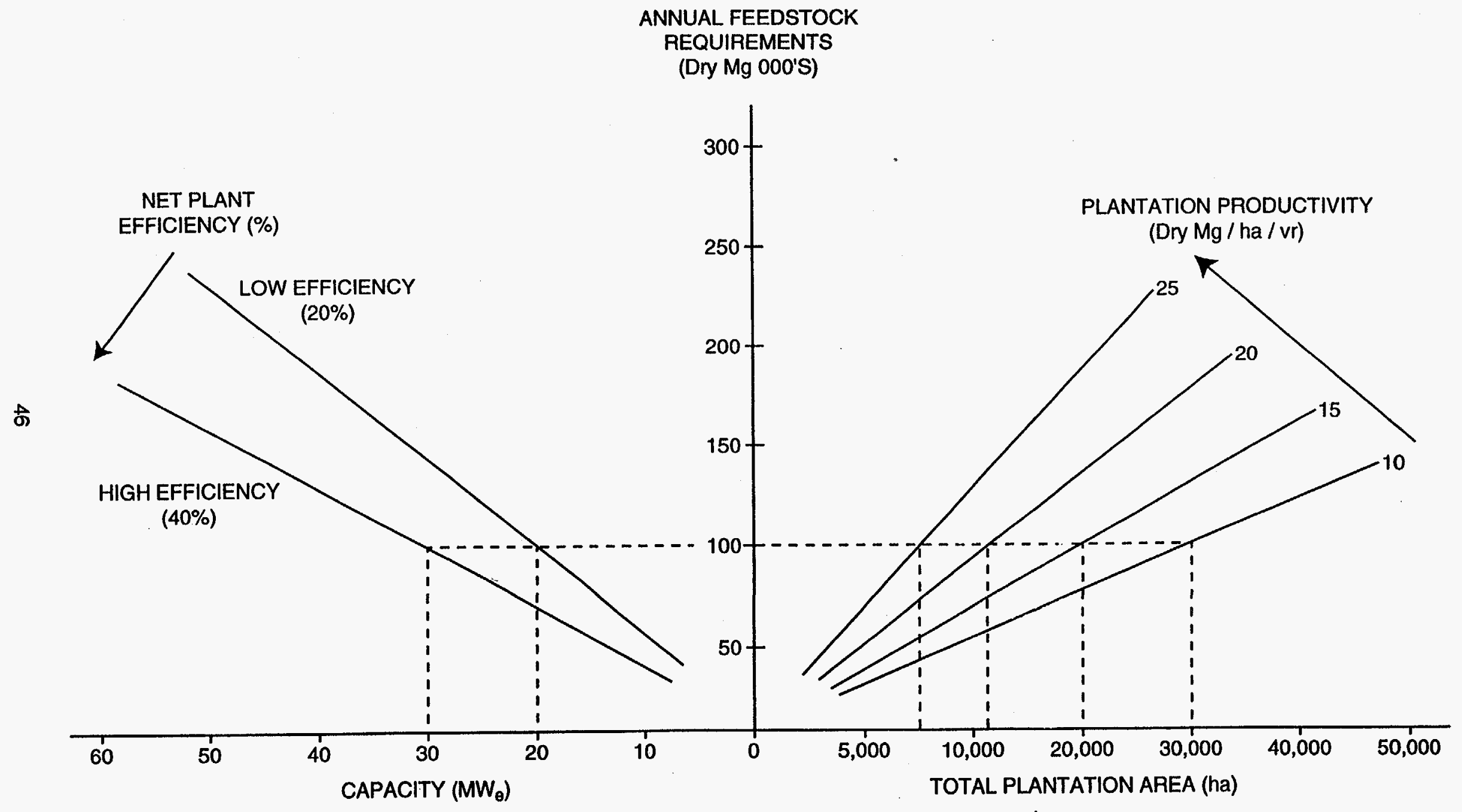

Fig. 5.1 The effect of biomass plant scale on feedstock requirements and transport distances. 
cropland, savannah, and arid wastelands. ${ }^{99}$ Growing populations and increasing needs for food production makes it unlikely that plantation feedstocks will be grown on cropland. ${ }^{100}$ The biomass productivity potential of marginal land is likely to be lower, and may not be sufficient to warrant investments in trees crops for power generation unless the opportunity cost or land rent of these lands is also low.

In a recently completed assessment of the economic status of energy crops in the U.S., total plantation establishment costs on cropland were estimated at about $\$ 580 /$ hectare. $^{101}$ This estimate included factor costs for site preparation (plowing and disking), planting, and weed control (cultivation and herbicide spraying). Planting is the single largest establishment cash expense. The estimate is generally applicable for a variety of woody crops (hybrid poplar, silver maple, sweetgum, black locust, and sycamore) grown in the Northeast, Southeast, Midwest, Lake States, and Pacific Northwest.

The relatively low-cost of plantation establishment is because the land does not require clearing or extensive tillage and weed control, and there are essentially no site limitations or the need for significant quantities of soil amendments, such as fertilizers. However, when extensive site preparation and fertilization is required, establishment costs can easily exceed $\$ 1000 /$ hectare. ${ }^{102}$ For plantations in Hawaii, establishment costs approach $\$ 1400 /$ hectare. $^{103}$ Because land is a combination of recently harvested sugar cane land, abandoned cane land, and waste land that is steep, poorly drained, and rocky, factor costs for clearing and weed control are high (about 55\% of total establishment costs). Labor and fuel costs are also higher relative to the U.S. mainland. However, high establishment costs can be economically justified provided productivity is also commensurately high.

After the second year of growth, the management of plantations is not intensive requiring only one or two applications of fertilizer to maintain soil nutrient levels. These costs are minimal for the U.S. on good cropland (about $\$ 80 /$ hectare during each rotation of 5 to 7 years). Because of the poorer site conditions, higher factor costs, and the need for greater quantities of nutrients to support higher biomass productivity, fertilization costs are nearly $\$ 500 /$ hectare over a five-year rotation for plantations in Hawaii. Prior to harvest, total establishment and maintenance costs (undiscounted) are about $\$ 660 /$ hectare on good cropland on the U.S. mainland and about $\$ 1850 /$ hectare on caneland in Hawaii.

In Brazil, plantation establishment practices for large-scale industrial operations involve the use of disks and the construction of tree beds and check dams to prevent erosion. ${ }^{104}$ Following preparation, sites are planted and watered. As in the industrialized temperate regions, weed control is critical and done at least twice each year until canopy closure occurs. These establishment practices usually involve manual labor except in larger-scaled operations where herbicides are used for weed control. The costs of plantation establishment in Northeast Brazil range from about $\$ 580$ to $\$ 1170 /$ hectare with maintenance costs varying from about $\$ 140$ to $\$ 860 /$ hectare over a sevenyear rotation. ${ }^{105}$ Much of the variation in establishment costs is due to planting costs. Carpentieri et al. cite planting costs ranging from $\$ 371$ to $\$ 811 /$ hectare for Northeast Brazil. ${ }^{106}$

Where sites have been degraded or have physical limitations, site preparation must be more intensive. For example, severely degraded plantation sites in Southwest China require the construction of pits and terraces to halt further erosion and hold moisture. ${ }^{107}$ Composts are also used to supply nutrients and condition the soils. ${ }^{108}$ On grasslands and brushy sites in the Philippines, site preparation involves extensive land clearing (slashing and burning) prior to digging tree pits and planting. Owing to the scarcity of capital, equipment, and materials, site preparation and maintenance is done manually with hand tools. The number of labor days required to establish 
and maintain a wood energy plantation in Southwest China can range between 150 to 300 workdays/hectare depending on the degree of site degradation. ${ }^{109}$ In the Philippines, the average labor requirements for establishment and maintenance are about 170 days/hectare with most of this for clearing and brushing. ${ }^{110}$

The productivity and costs of plantation harvesting systems were discussed previously. These costs can be variable, generally ranging from about $\$ 18$ to $\$ 35 /$ dry tonne for mechanized felling, skidding, and chipping. For manual operations, the amount of labor required to harvest one hectare can vary considerably among sites. For the Southwest China and Philippines examples, these rates range from about 75 to over 130 workdays/hectare on average. The costs of harvesting (felling, cutting, and forwarding to a landing) for both examples are about $\$ 5 /$ dry tonne. In the case of Brazil, harvesting costs (not including chipping) are slightly higher (about $\$ 7 /$ dry tonne).

A summary of the costs of growing plantation fuels is shown in Table 5.1. Also shown is average productivity. Because of different factor input and financial assumptions, these estimates are not entirely comparable. For example, the developing country examples do not include chipping. Feedstock size reduction is part of the fuel preparation process at the conversion facility. The Southwest China example does not include land rent since there is little opportunity cost associated with degraded hillside land. In spite of these caveats, these estimates can be used to provide a general indication of cost and how competitive plantation feedstock production is likely to be. On the basis of the costs of coal, currently at less than $\$ 2.00 / \mathrm{GJ}$ in most of the world, these feedstocks are not competitive. Where coal is unavailable at low cost, plantation feedstock production can be competitive with other alternatives.

The costs of plantation-grown feedstocks in any given country will vary considerably because of localized variations in land quality or biomass productivity, land rents, and other factor inputs. This localized variation in delivered feedstock costs can be illustrated by the data from Northeast Brazil, where average wood costs range from a low of about $\$ 1.00 / \mathrm{GJ}$ to $\$ 4.60 / \mathrm{GJ}$ across five bioclimatic regions. This relationship is displayed in Fig. 5.2 for the five bioclimatic regions. The high and low estimates of delivered feedstock costs are based on the use of high and low estimates for land, planting costs, and productivity differences, which range between 3 and 21 dry tonnes/ha. ${ }^{111}$ The costs of producing biomass in each bioclimatic region can be associated with land availability to determine the average cost of supplying plantation-grown feedstocks in Northeast Brazil. This feedstock supply curve is shown in Fig. 5.3. The curve is upward sloping indicating the quantities of feedstock that are available at any given delivered cost are limited. For example, about $5000 \mathrm{GJ}$ of feedstocks are potentially available at costs of about $\$ 1.25 / \mathrm{GJ}$. An additional $7000 \mathrm{GJ}$ are available annually for costs of about $\$ 1.60 / \mathrm{GJ}$. Due to the scarcity of land, the cost of plantation feedstocks increase sharply beyond annual production of $12000 \mathrm{GJ}$.

Table 5.1. Summary of the Costs and Productivity of Plantation-grown Fuel ${ }^{112}$

\begin{tabular}{lcc}
\hline Country & $\begin{array}{c}\text { Delivered feedstock } \\
\text { costs }(\$ / G J)\end{array}$ & $\begin{array}{c}\text { Average productivity } \\
\text { (dry tonnes/ha/yr) }\end{array}$ \\
\hline United States (mainland) & $\$ 1.90-\$ 2.80$ & $10-15.5$ \\
Hawaii & $\$ 2.06-\$ 3.20$ & $18.6-22.4$ \\
Portugal & $\$ 2.30$ & 15.0 \\
Sweden & $\$ 4.00$ & $6.5-12.0$ \\
Brazil (Northeast) & $\$ 0.97-\$ 4.60$ & $3.0-21.0$ \\
China (Southwest) & $\$ 0.60$ & 8.0 \\
Philippines & $\$ 0.42-\$ 1.18$ & 15.4 \\
\hline \hline
\end{tabular}




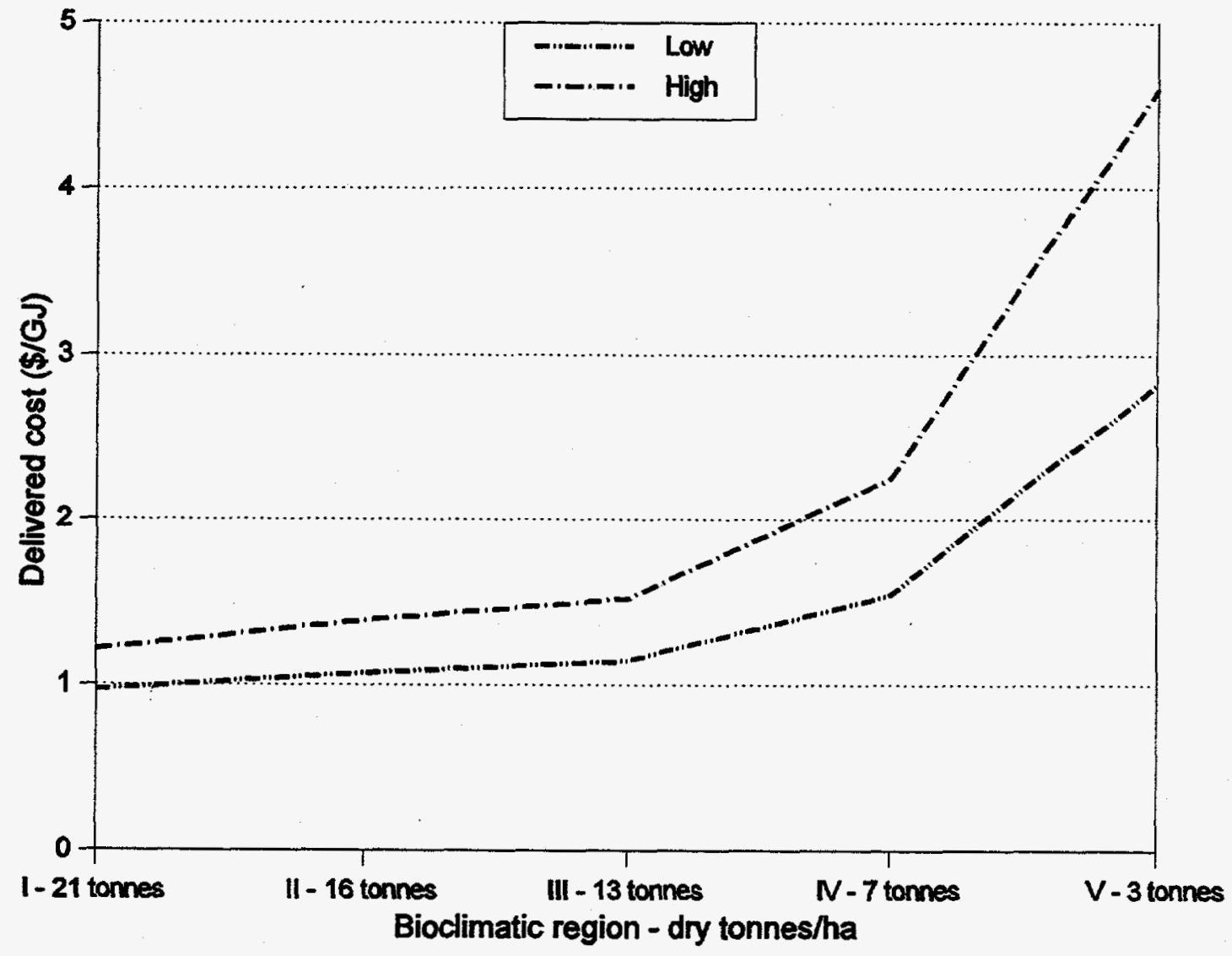

Fig. 5.2. Variation in delivered feedstock costs by bioclimatic region in Northeast Brazil. ${ }^{113}$ 


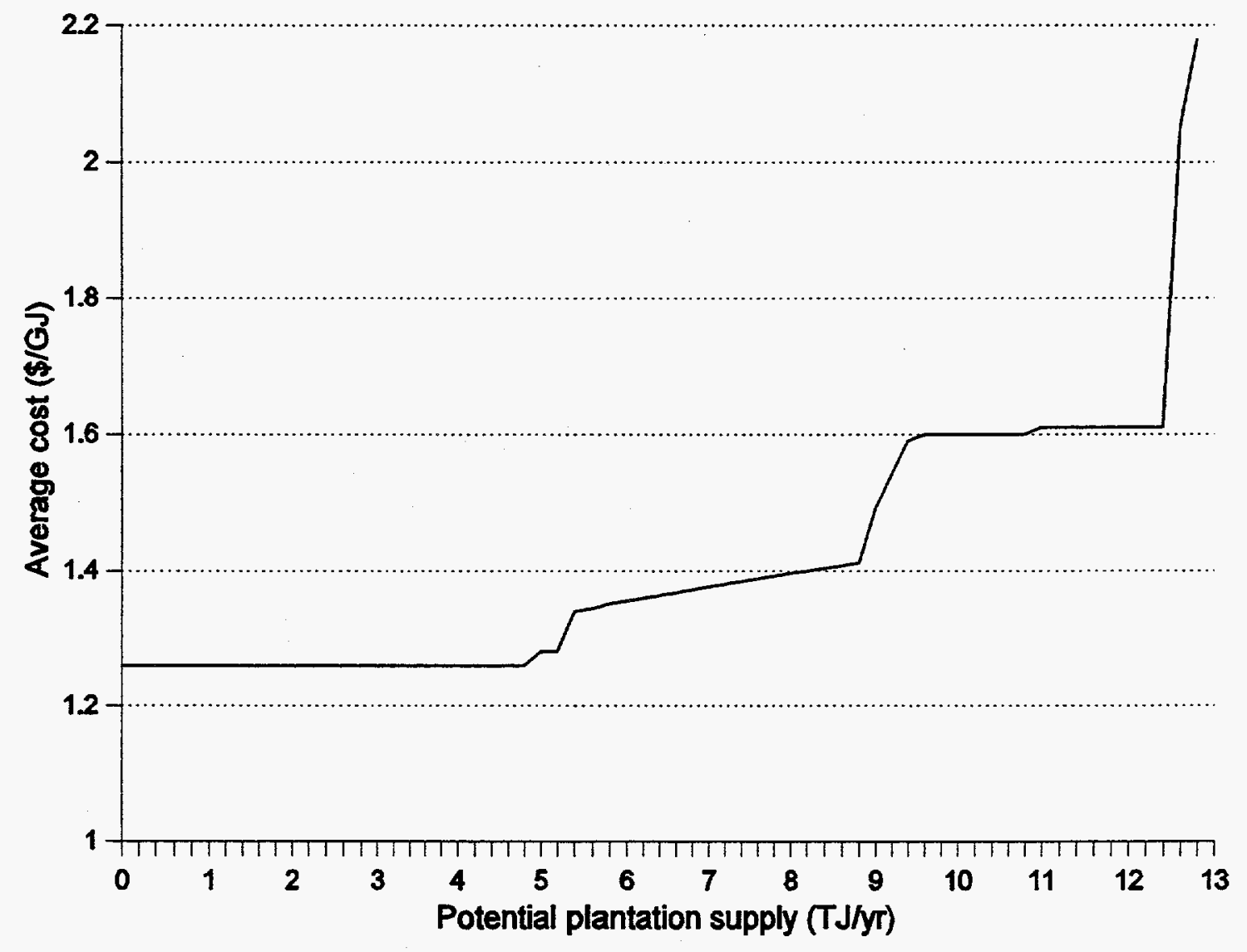

Fig. 5.3. Average cost of plantation-grown feedstocks in . Northeast Brazil. ${ }^{114}$ 


\section{THE COSTS OF POWER PRODUCTION FROM PLANTATION FUELS}

Biomass-based power generation is often competitive with fossil alternatives provided a lowcost supply of feedstock is available. This fact tends to hold true even considering that conventional biomass steam-turbine technology is capital intensive and inefficient at scales appropriate for biomass. Figure 5.4 illustrates the relationship betwen the cost of power $(\$ / \mathrm{kWh})$ and fuel cost (\$/GJ). The low efficiency line in Fig. 5.4 represents a conventional steam-turbine facility having an installed cost of about $\$ 1900 / \mathrm{kW}$ with an efficiency of about $23 \%$. Generating power at costs (busbar) of $\$ 0.05 / \mathrm{kWh}$ would require a feedstock supply costing less than $\$ 1 / \mathrm{GJ}$.

In the U.S. and Europe, efforts are underway to develop lower capital cost and higher efficiency biomass conversion technology. This technology would make the use of plantation-grown fuels much more competitive with currently available fossil-fired alternatives. Figure 5.4 illustrates the effect of lower capital cost and higher efficiency technology. This example is based on biomass integrated gasifier/combined cycle (BIG/CC) technology currently under development and demonstration in Northeast Brazil. The line labeled high efficiency is for a plant costing $\$ 1300 / \mathrm{kW}$ installed with a system efficiency of slightly more than $35 \%$. Comparing this high efficiency technology with the conventional, low effieciency technology shows a difference of about $\$ 0.02 / \mathrm{kWh}$ in power costs or about $\$ 2 / G \mathrm{~J}$ in terms of fuel cost. This example indicates that power could be produced at $\$ 0.05 / \mathrm{kWh}$ with fuel costs of about $\$ 2.80 / \mathrm{GJ}$. At this fuel cost, plantation-grown feedstocks would be much more competitive with conventional alternatives even before considering the other environmental and developmental benefits of biomass energy.

\section{CONCLUSIONS}

In this report, the biologic, environmental, economic and operational issues were stressed for plantation-grown woody crops. The report did not stress conversion technology. Those interested in learning more about conversion processes may want to consult the references contained in the end-notes to this Report. It is hoped that this Report will help planners and decision makers when they consider the use of woody crops for power generation as a either a dedicated feedstock or as a supplement to an existing residue or waste fuel.

The background used in highlighting the worldwide experience with plantation-grown feedstocks was drawn from firsthand observations, personal contacts, and secondary information and data sources. Although the authors have attempted to incorporate as much as information as possible on the status of plantation-grown fuels for power generation, there is, no doubt, that some relevant experiences with plantation fuels should have been included in this report. Oak Ridge National Laboratory would greatly appreciate receiving any information that would be relevant to include in an updated version of this report. As can be inferred from this report, biomass systems (feedstock production, handling and logistics, and conversion) are very complex and potentially difficult to implement; however, biomass energy offers many benefits both locally and globally. Sharing common experiences is one-way to overcome the inertia in getting plantation-grown fuels from the research and demonstration stage to initial commercialization and eventually wide-scale use. 


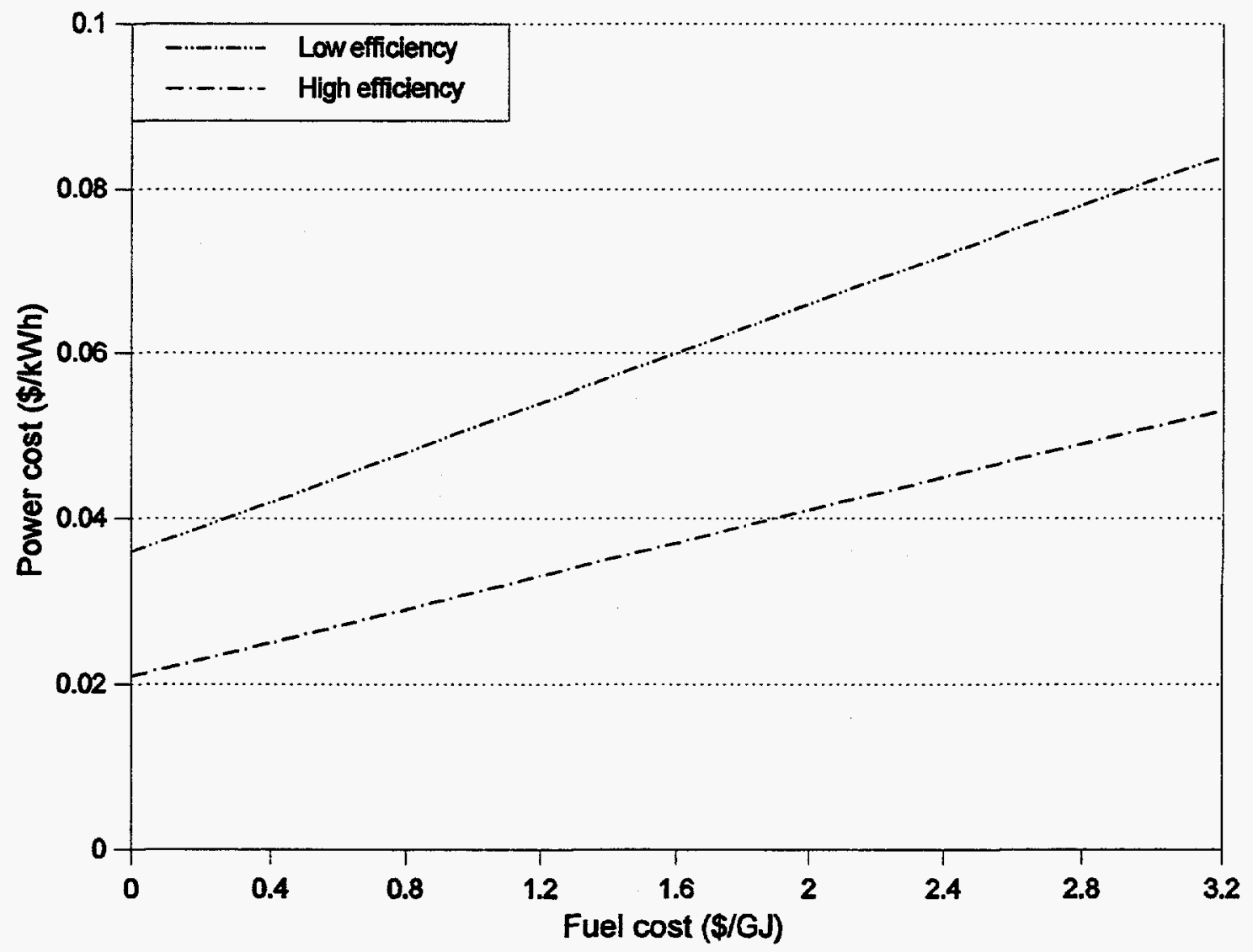

Fig. 5.4. The effect of fuel cost on power costs for a low-efficiency (conventional steamturbine) technology and a high-efficiency, low-capital cost technology. 


\section{NOTES AND REFERENCES}

1. Hall, D. O. and J. Woods, "Biomass: Past, Present and Future," ed. by M. Kuliasha et al., Technologies for a Greenhouse Constrained Society, Lewis Publishers, Chelsea, Michigan, 1992.

2. For example, in the United States the amount of biomass-fired electric generating capacity increased more than thirty-fold during the 1980s. Total installed capacity is now about $9 \mathrm{GW}$ with nearly $90 \%$ of this generating capacity connected to utility grids. This growth in biomass energy use was a direct result of the Public Utility Regulation Policy Act (PURPA) of 1978, which requires utilities to purchase power from independent power producers at avoided costs.

3. Betters, D. R. et al., "Short-rotation Woody Crop Plantations in Brazil and the Unites States," Biomass and Bioenergy, 1991, 1(6):305-316.

Couto, L. et al., "Energy from Wood Biomass: The Experience of the Brazilian Forest Sector," p. 42-53 In: Proceedings of the First Biomass Conference of the Americas, 1993, NREL/CP200-5768, National Renewable Energy Laboratory, Golden, Colorado.

4. Couto, L. and D. R. Betters, Short-rotation Eucalypt Plantations in Brazil: Social and Environmental /ssues, prepared for the Biofuels Feedstock Development Program, 1995, ORNL/TM-12846, Oak Ridge National Laboratory, Oak Ridge, Tennessee.

5. Couto, L. 1994. (personal Communication). Couto indicates that the recent changes in the Forestry code were causing companies to reduce energy plantation establishment. This was also indicated by more than one contact made by Lynn Wright on a visit in 1994 to several institutions and companies in Brazil. However, companies are continuing to plant for pulp production or where multiple products are being obtained from the wood.

6. Ledin, S. and A. Alriksson, "Country Report for Sweden," Handbook on How to Grow Short Rotation Forests, 1992, Swedish University of Agricultural Sciences. Uppsala, Sweden.

7. Durst, P., Energy Plantations in the Republic of the Philippines, SE-265, 1987, U.S. Department of Agriculture, Southeastern Forest Experiment Station.

8. Ranney, J.W. et al., "Hardwood Energy Crops: The Technology of Intensive Culture," J. Forestry, 1987, 85(9): 17-28.

9. This discussion draws heavily on a report by Durst op. cit., 1987.

10. A stacked cubic meter (stere) averaging $400 \mathrm{~kg}$ of wood (green weight).

11. Durst op. cit., 1987.

12. Durst op. cit., 1987.,

13. An comprehensive overview of the Hawaiian experience can be found in C.D. Whitesell, et al., Short-Rotation Management of Eucalyptus: Guidelines for Plantations in Hawaii, General Technical Report PSW-GTR-137, November 1992, US Forest Service. 
14. Wasteland is defined as land that had never been in cane production. This land is steep, poorly drained, and rocky. Forest land is secondary forest zoned for agriculture. Little development of forest land occurred, however, because the cost of clearing and developing access roads was too costly.

15. Florence, R. G., "Cultural Problems of Eucalyptus as Exotics," Commonwealth Forest Review, 1986, 65:141-163.

16. Lynn Wright visited Hawaii in November 1994 to evaluate the status of forestry activities and learned of the very recent acquisition by Bishop Estates of 12,000 ha of land.

17. Cuoto et al., op. cit., 1993.

18. Information on Brazil's farm forestry experience is from E. D. Larson et al., "Farm Forestry in Brazil," Bioresources '94, Biomass Resources: A means to Sustainable Development, Bangalore, India, October 3-7, 1994. Although Betters et al., 1991, converts $35 \mathrm{~m}^{3}$ and $70 \mathrm{~m}^{3}$ to 29 and $56 \mathrm{dry}$ tonnes/ha/yr, we believe that was based on a high density value for evalyptus that is not representative of average value. We use a conversion value of $0.47 \mathrm{dry}$ tonnes $/ \mathrm{m}^{3}$ instead.

19. Betters et al., op. cit., 1991.

20. Tecflor, "Determinaċão da Padrões Técnicos Médios e Custos de Operacões Florestais em Areas de Topografia Plana e Inclinada, para Fins de Planejamento Florestal." Vićosa, Minas Gerais, Brazil, 1989.

21. Graća, L. R., J. B. Mendes, "Análise Econômica de Sistemas de Reflorestamento de Bracatinga," EMBRAPA-CNPF, Boletim de Pesquisa Florestal, 1987, 14:55-63.

22. Reis, M. G. F., "A Contribuićão da Pesquisa Florestal Pere a Reducão de Impactos Ambientais dos Reflorestamentos," In / Simpósio Brasileiro de Pesquisa Florestal, 18 pp. Belo Horizonte, Minas Gerais, Brazil, SIF 1993.

23. Ranney, J. W. "Short-rotation Wood Energy Crop Improvement and Commercialization in Tropical and Temperate Zones," presented at meeting on The Potential of Biomass Products, Energy Utilization Forum, June 10-12, 1994, Taipei, Taiwan.

24. For example, see Barros and Novais, 1990, were soils low in essential nutrients were managed effectively for agriculture and forestry in Brazil.

25. Jordan, C.F., "Productivity of tropical rain forests ecosystems and the implications for their use as future wood and energy sources,"in Tropical Rain Forest Ecosystems: Structure and Function, Ecosystems of the World, 14a. ed. F.B. Golley, Elsevier Scientific: Amsterdam, 1983 pp. 117-136.

26. Wright L. L., "Production Technology Status of Woody and Herbaceous Crops," Biomass and Bioenergy, 1994, 6(3): 191-210.

Hall, D. O., F. Rosillo-Calle, R. Williams, and J. Woods, "Biomass for Energy: Supply Prospects," in Renewable Energy: Sources for Fuel and Electricity, ed. T. B. Johonsson, H. Kelly, A. Reddy, and R. Williams, Island Press, Washington, DC, 1993.

Whitesell et al., op. cit., 1992. 
White, E., Bioenergy From Willow, Progress Report, State University of New York, College of Environmental Science and Forestry, Syracuse, New York, 1995.

Willebrand, E. S., S. Ledin, and T. Verwijst, "Willow Coppice Systems in Short-Rotation Biomass Production," Biomass and Bioenergy, 1993, 4(5):323-331.

Christerson, L. “Biomass Production by Irrigated and Fertilized Salix Clones, Biomass, 1987, 12:83-95.

Carpentieri, A. E., E. D. Larson, and J. Woods, “Future Biomass-Based Electricity Supply in Northeast Brazil," Biomass and Bioenergy 1993, 4:149-174.

27. Phillips V.D. et al., "Biomass System Model Estimates of Short-rotation hardwood production in Hawaii," Biomass and Bioenergy, 1993, 5(6):421-429.

28. Singh, D. et al., "Identifying Land Potentially Available for Biomas Plantations in Hawaii," Agricultural Systems, 1993, 41:1-22.

29. Zobel, B.J., and J.T. Talbert, Applied Forest Tree Improvement, 1984, Wiley, New York.

30. Wright op. cit., 1994.

31. Evans, J., Plantation Forestry in the Tropics, Second Edition, 1992, Oxford University Press, Oxford.

32. Ontario Ministry of Natural Resources, A Grower's Guide to Hybrid Poplar, undated, Toronto.

33. Pat Layton, Scott Paper Company, personal communication, 1994.

34. Whitesell et al., op. cit., 1992.

Ledin, S. and A. Alriksson, Handbook on How to Grow Short Rotation Forests, 1992, Swedish University of Agricultural Sciences, Uppsala.

Phillips et al., op. cit., 1993.

Betters et al., op. cit., 1991.

35. Couto and Betters, op. cit., 1994.

Ranney, J.W. and L.K. Mann, "Environmental Consideration in Energy Crop Production," Biomass and Bioenergy, 1994, 6(3):211-230.

Evans, op. cit., 1992.

Whitesell et al., op. cit., 1992.

36. Couto. L., et al., "Agroforestry as an alternative to reduce establishment costs of short-rotation eucalyp plantations in southeastern Brazil," in Opportunities for Agroforestry in the Temperate Zone Worldwide, proceedings of Third North American Agroforestry Conference, August 1518, 1993, lowa State University, Ames. lowa. 
37. Newman, D.R., and D.O. Hall, "Land-use Impacts," in Bioenergy and the Environment, ed. J. Pasztor and L.A. Kristoferson, Westview Press, Boulder, Colorado, 1990, p. 212-265.

Lundgren, B.O. The Use of Agroforestry to Improve the Productivity of Converted Tropical Land, ICRAF (Intl. Council Research Agroforestry),1982, Nairobi.

Beets, W.C. Agroforestry in African Farming Systems, Energy/Development International for USAID, 1985, Washington, DC.

38. Shell/WWF, Tree Plantation Review, Guidelines, Shell International Petroleum and World Wide Fund for Nature, 1993, Godalming, Surrey (GU7 1XR, England).

Couto and Betters, op. cit., 1995.

39. Christersson, L. et al., "Pests, Diseases and Injuries in Intensive Short-Rotation Forestry," in Mitchell, C.P. et al., (eds), Ecophysiology of Short-Rotation Forest Crops, Elsevier Applied Science, London,1992, p. 308.

40. Christersson et. al., op. cit., 1992.

41. See, Ledin and Alriksson, op. cit., 1992, for a comprehensive discussion of harvest machinery being developed in International Energy Agency (IEA) countries.

42. Stokes et al., "Development and Analysis of SRIC Harvesting Systems," Proceedings of the First Biomass Conference of the Americas, Sponsored by the U.S. Department of Energy, Energy, Mines, and Resources of Canada, U.S. Department of Agriculture, and the Environmental Protection Agency, Published by the National Renewable Energy Laboratory, NREL/CP-200-5768, DE93010050, Burlington, Vermont, August 30 - September 2, 1993.

43. Ibid.

44. Lie, W. et al., "Estimating short-rotation," Eucalyptus saligna producing in Hawaii; an integrated yield and economic model, Bioresource Technology, 1993, 45:167-176.

Liu, W. et al., "A Spatial Model for the Economic Evaluation of Biomass Production Systems," Biomass and Bioenergy, 1992, 3:345-356.

Merriam, R. A. et al., "Space/Age Forestry: Implications of Planting Density and Rotation Age on SRIC Management Decisions," in proceedings of the First Biomass Conference of the America, Burlington, Vermont, August 30 - September 2, 1993.

45. For example, see Stokes and Hartsough op. cit., 1994; Whitesell et al., op. cit., 1992; and Ledin and Alrikkson op. cit., 1992.

46. Harvesting system costs are also dependent on a host of technical and economic factors including: the tree diameter size; the physical layout of the plantation (in-row and between row spacing); the number of trees per hectare; tract size and the number of site moves relative to the total area; equipment cost, utilization (available machine time versus productive machine timel, and down time; labor requirements and costs; and terrain and weather conditions.

47. WTE ${ }^{\text {m }}$ technology is under development by Energy Performance Systems, Inc. A discussion of the technology and costs can be found in Perlack, R. D., M. Walsh, L. Wright, and D. Ostlie, 1995. The Economic Potential of Whole-Tree Feedstock Production, Draft Manuscript, Oak Ridge National Laboratory, Oak Ridge, Tennessee. 
48. WTE harvesting is estimated at $\$ 5$ to $10 /$ dry tonne depending on assumptions about tree size and equipment operating speed (Perlack et al., 1995). This estimate included felling, accumulating, and loading of whole trees onto trailers. It did not include chipping or any other processing.

49. Betters et al., op, cit., 1991.

50. Perlack, R.D., et al., Biomass energy development in Yunnan Province, China: Preliminary Evaluation ORNL/TM-11791, 1991 Oak Ridge National Laboratory, Oak Ridge, TN.

51. Durst op. cit., 1987.

52. Denton, F., Wood for Energy and Rural Development: The Philippine Experience, Frank H. Denton, Manila, September 1983.

53. The data in this Table are adapted from Stokes, B., "Status of Short-Rotation Forestry in the USA", International Energy Agency/Bioenergy Agreement, Task IX Harvesting and Supply of Woody Biomass for Energy, Harwell Laboratory, 1993, Oxford, England.

54. Elliot, G., 1994, personal communication.

55. Lyons, G.,J., "Harvesting, Drying and Storage of Short-Rotation Forestry Energy Crops," Biomass Energy from Harvesting to Storage, ed. by G. Ferraro, G. Grassi, and H. Williams, Elsevier Applied Science, London, 1987.

56. Wright op. cit., 1994.

57. Some operational problems with long-term fuel storage can be avoided by using multiple fuels that have different harvest periods. For example, the U.S. is looking at systems that use a combination of wood and herbaceous feedstocks each with different harvest windows. Fuel storage problems can also be alleviated by using waste resources, such as bagasse, rice hull, and wood mill wastes.

58. Relative to modern coal-fired steam turbine systems, biomass plants have lower net plant efficiencies.

59. Williams, R. and E. Larson, "Biomass-Gasifier Gas Turbine Power Generating Technology," Proceedings: Strategic Benefits of Biomass and Waste Fuels, Electric Power Research Institute, EPRI TR-103146, Palo Alto, California, December 1993.

60. A number of reports and papers are available that describe in detail biomass conversion technologies. Among these are:

U. S. Department of Energy (DOE), Electricity From Biomass, Solar Thermal and Biomass Power Division, DOE/CH 10093-152, 1992, Washington.

Tennessee Valley Authority (TVA) Biomass Design manual: Industrial Size Systems; Southeast Regional Biomass Program, 1991, Muscle Shoals, Alabama.

Easterly, J. L. And M. Z. Lowenstein, Cogeneration from Biofuels: A Technical Guidebook, Southeast Regional Biomass Program, Muscle Shoals, Alabama.

Hollenbaker, op. cit., 1992. 
Winrock International Institute for Agricultural Development, Industrial Energy and Electricity from Wood Residues, Prepared by Dean B. Mahin, Arlington, Virginia, June 1991.

61. For some applications alkali slagging and erosion of boiler surfaces can occur.

62. Lamarre, L., 1994, "Electricity from Whole Trees," EPRI Journal, January/February.

63. EPS,. A New Electrical Generation Technology Has Now Arrived, Energy Performance Systems, 1993,Minneapolis.

64. Williams, and Larson, op. cit., 1993.

65. Ibid.

Williams, R. H. et al., "Advanced Biomass Power Generation: The Biomass-Integrated Gasifier/Gas Turbine and Beyond", in Technologies for a Greenhouse-Constrained Society, M. A. Kuliasha, et al., (eds), Publishers, USA., 1991.

63. See Williams and Larson, "Advanced Gasification-Based Biomass Power Generation," in Renewable Energy, Johansson et al., (eds), Island Press, 1992.

67. The Global Environmental Facility (GEF) is currently funding the demonstration of a BIG/GT combined cycle.

68. U.S. Department of Energy (DOE), op. cit., 1992.

69. Douglas, "Beyond Steam: Breaking Through Performance Limits," EPRI Journal, December 1990.

70. Graham, R. L. The Regional Environmental Impact of Biomass Plantations, Proceedings of Meeting on the Potential of Biomass Products Energy Utilization Forum, Taipei, Taiwan, Oak Ridge, Tennessee, June 1994.

71. Graham R. L., L. L. Wright, and A. F. Turhollow, "The Potential for Short-Rotation Woody Crops to Reduce U.S. CO² Emissions," Climate Change, 1992, 22:223-238.

Graham op. cit., 1994.

72. Newman, and Hall op. cit., 1990.

Van Goor, C.P. "The impact of tree species on soil productivity." Netherlands Journal of Agriculture Science, 1985, 33:133-140.

73. Ranney, and Mann, op. cit., "Environmental Consideration in Energy Crop Production." Biomass and Bioenergy, 1994, 6(3).

74. Beyea, J. et al., Toward Ecological Guidelines for Large-Scale Biomass Energy Development, National Audubon Society and Princeton University, New York and Princeton, 1991.

Shell/WWF op. cit., 1993.

75. Couto and Better op. cit. 1994.

Eldridge et al., 1993 
76. Newman, D.R., and D.O. Hall, "Land-use Impacts," Bioenergy and the Environment, J. Pasztor and L.A. Kristoferson (eds),1990, Westview Press, Boulder, Colorado.

Beyea et. al., op, cit,. 1991.

Shell/WWF op, cit, 1991.

77. National Biofuels Roundtable, Principles and Guidelines for the Development of Biomass Energy Systems: Draft Final Report, Available from R. Overend, National Renewable Energy Laboratory, Golden, CO, 1994.

78. Blakie, P., The Political Economy of Soil Erosion in Developing Countries, 1985, Longman, London.

Biswas, A., Environmental concerns in Pakistan, with special reference to forests and water. Environmental Conservation, 1987, 144:319-28.

79. Leach D., and R. Mearns, Beyond the Woodfuel Crises: people, land, and trees in Africa, Earthscan Publ., 1989, London.

Shiva and Bandyopadhya, Central Soil and Water Conservation Institute, 1987.

80. Lima, W.P. et al ., Comparative evapotranspiration of Eucalyptus, pine, and Cerrado vegetation measured by the soil water balance method, IPEF International, Piracicaba, 1990, 1:5-11.

81. Blakie op. cit. 1985.

Leach and Mearns op. cit. 1989.

Beets, W.C., Agroforestry in African Farming Systems, Energy/Development International for USAID, 1985, Washington, DC.

Lundgren B.O., The Use of Agroforestry to Improve the Productivity of Converted Tropical Land. ICRAF (Intl. Council Research Agroforestry), 1982, Nairobi.

82. Ibid, The Use of Agroforestry to Improve the Productivity of Converted Tropical Land, ICRAF (Intl. Council Research Agroforestry), 1982, Nairobi.

83. Allen, J.C. and J.C. Cady, Impact of Forest Soils on the Bioenergy Outlook in Developing Countries, Resources for the Future, 1982 Washington, DC.

84. Newman and Hall, op. cit., 1990.

85. Hoffman, W., et al., Some ecological guidelines for large-scale biomass plantations, in proceedings of the First Biomass Conference of the Americas, Volume I, pages 33-41. NREL/CO-200-5768, 1993, National Renewable Energy Laboratory, Golden, Colorado.

86. Kelly, T.D., et al., Impact of agroforestry plantations growth with agricultural drainwater on avian abundance in the San Joaquin Valley, California, Transactions of the Western Section of the Wildife Society, 1990, 26:97-103.

Beyea et. al., op. cit., 1991 , 
87. Wilcove, D. S., "Nest Predation in Forest Tracts and the Decline of Migratory Songbirds," Ecology, 1989, 66:1211-14.

Loyn, R. H. "Bird Populations in a Mixed Eucalypt Forest Used for Production of Wood in Gippsland, Victoria," Emu, 1980, 80:145-56.

88. Shell WW op. cit., 1991.

Beyea op. cit., 1991.

89. Couto and Betters op. cit., 1995.

90. Graham op. cit., 1994.

Graham R. L. and M. Downing, "Renewable Biomass Energy: Understanding Regional Scale Environmental Impacts," pp. 1566-1581 in First Biomass Conference of the Americas: Energy, Environment, Agriculture, and Industry, National Renewable Energy Laboratory, Golden, CO, 1993.

Barros, personal communication, University of Vigosa, Minias Gerais, Brazil, 1994.

91. Rosillo-Calle F. and D. Hall, "Brazilian Alcohol: Food Versus Fuel," Biomass, 1987, 12:97-129.

92. Shell/WWF op. cit., 1993.

Newman and Hall,op. cit., 1990.

93. Beets op. cit., 1985.

Leach and Mearns op. cit., 1989.

94. Couto, 1994, personal communication.

95. National Biofuels Roundtable op. cit., 1994.

96. A relatively thorough overview of short-rotation forestry practices can be found in Ledin and Alriksson (1992). The work of a research team at the University of Hawaii (Manoa) is also instructive (Singh et al. 1993; Phillips et al. 1993; and Phillips et al. 1993b)

97. It is estimated that more than 15 million ha of cropland is suitable and likely to be available for energy crops in the U.S. (Wright and Ranney, 1993). If drought resistant crops are developed, the potential land base could be over 70 million ha (Betters et al., 1991).

98. A comprehensive overview of the potential environmental impacts of energy plantations can be found in OTA, 1993.

99. Walstad (1991) notes for Brazil the conversion of over 100,000 ha of low-value forest stands to plantation forestry in the northeast and the current planting of over 100,000 ha/year of deforested land in Minas Gerais (Brazil).

100. Agroforestry approaches involving the growing of trees and crops in various spacial arrangements (e.g., alley cropping) is also an option for producing energy feedstocks. 
101. Perlack R.D. and L.L. Wright, 1995, "Economic Status of Dedicated Biomass Feedstock Supply Systems," Energy: The International Journal, 20:279-284.

102. Houtari et al. (1993) summarize the costs of establishing short-rotation plantations in the industrialized countries. Their average is $\$ 2000 /$ hectare with a delivered fuel cost of over $\$ 4.00 / G J$. For some factors (e.g., planting) they report order of magnitude cost ranges. However, there is not sufficient detail in their report to understand the basis for such high plantation costs.

103. Whitesell et al., op. cit., 1995.

104. Betters op. cit., 1991.

105. Couto et. al., op. cit., 1993.

106. Carpentieri et al., op, cit., 1993.

107. A comprehensive overview of short-rotation forestry practices in the tropics can be found in Evans, 1992.

108. Perlack et. al., op. cit., 1991.

109. Perlack and Wright op. cit., 1995.

World Bank, Fuelwood Development and Conservation Project: Hunan Province, Report of the World Bank and United Nations Development Program, Energy Sector Management Assistance Program, Washington, December 1989.

110. Durst op. cit., 1987.

111. Carpentieri et. al., op. cit., 1993.

112. Perlack and Wright op cit., 1994.

Whitesell et al., op cit., 1992.

Williams op cit., 1994.

Carpentieri et al., op cit., 1993.

Perlack et al., op cit., 1991.

Durst op cit., 1987.

113. Carpentieri op. cit., 1993.

114. Carpentieri op. cit., 1993. 


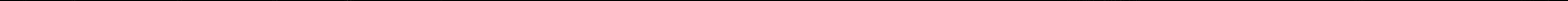




\section{INTERNAL DISTRIBUTION}

$\begin{aligned} \text { 1-5. } & \text { K. R. Ballew } \\ 6 . & \text { M. A. Brown } \\ 7 . & \text { G. E. Courville } \\ 8 . & \text { T. R. Curlee } \\ 9 . & \text { J. H. Cushman } \\ \text { 10. } & \text { S. Das } \\ \text { 11. } & \text { M. E. Downing } \\ \text { 12. } & \text { M. P. Farrell } \\ \text { 13. } & \text { R. L. Graham } \\ 14 . & \text { S. G. Hildebrand } \\ 15 . & \text { L. J. Hill } \\ 16 . & \text { E. L. Hillsman } \\ \text { 7-21. } & \text { M. A. Huston } \\ 22-71 . & \text { R. D. Perlack } \\ 72 . & \text { C. I. Moser }\end{aligned}$

1-5. K. R. Ballew

6. M. A. Brown

7. G. E. Courville

8. T. R. Curlee

9. J. H. Cushman

10. S. Das

11. M. E. Downing

12. M. P. Farrell

13. R. L. Graham

14. S. G. Hildebrand

15. L. J. Hill

16. E. L. Hillsman

22-71. R. D. Perlack

72. C. I. Moser
73. D. E. Reichle

74-78. W. E. Schramm

79. J. Sheffield

80. R. B. Shelton

81. V. R. Tolbert

82. A. W. Trivelpiece

83. G. A. Tuskan

84. M. E. Walsh

85. T. J. Wilbanks

86-135. L. L. Wright

136. ORNL Patent Office

137. Central Research Library

138. Document Reference Section

139-141. Laboratory Records

142. Laboratory Records-RC

\section{EXTERNAL DISTRIBUTION}

143. Rich Bain, National Renewable Energy Laboratory, 1617 Cole Blvd. Golden CO 80401-339

144. David Betters, Rm 129 Forestry Bldg. Colorado State University, Ft. Collins, CO 80523

145. Dale Bradshaw, Tennessee Valley Authority, 1101 Market Street, Chattanooga, TN 37402.

146. Mr. G. D. Burch, Director, Solar Thermal \& Biomass Division (EE-132), DOE, Washington, DC 20585

147. J. E. Ferrell, Acting Director, Biofuels System Division (EE-331), DOE, Washington, DC 20585

148. Laercio Couto, Forestry Department, Federal University of Vicosa, Vicosa, Minas Gerias, Brazil 36570

149. Thomas E. Drabek, Professor, Department of Sociology, University of Denver, Denver, Colorado 80208-0209

150. W. Fulkerson, JIEE, 327 S. Stadium Hall, Knoxville, TN 37996-0710

151. Marcia Gowen, Alternative Energy Development, Inc. 8455 Colesville Road Suite 1225, Silver Spring, MD 20910 


\section{EXTERNAL DISTRIBUTION - continued}

152. Ed Gray, Antares Group, 8240 Professional Place, Suite 207, Landover, MD 20785

153. Wenonah Hauter, Union of Concerned Scientists, 1616 P Street NW, Suite 310 , Washington, D.C. 20036

154. William Hohenstein, Environmental Protection Agency, $401 \mathrm{M}$ Street, Rn 3220, Washington, D.C. 20024

155. John Holt, National Rural Electric Cooperative Association, 1800 Massachusetts Ave NW, Washington, D.C. 20036

156. Evan Hughes, Electric Power Research Institute,PO Box 10412, Palo Alto CA 94303

157. Valdimir Jadrijevic, The World Bank, 1818 H Street N.W., Washington D.C. 20433

158. John Kinsman, Edison Electric Institute, 701 Pennsylvania Ave NW, Washington D. C. 20004-2696

159. Robert Kirmse, The World Bank, 1818 H Street NW, Washington, D.C. 20433

160. Keith Kozloff, World Resources Institute, 1709 New York Ave NW, Washington D.C. 20006

161. Charles E. Noon, University of Tennessee, 613 Stokely Management Center, Knoxville, Tennessee, 37996-0562

162. Ralph Overand, National Renewable Energy Laboratory,1617 Cole Blvd. Golden CO 80401-339

163. Victor Phillips, College of Tropical Agriculture, 3050 Maile Way, Gilmore 214, Honolulu, Hawaii 96822.

164. J. W. Ranney, JIEE,327 S. Stadium Hall, Knoxville, TN 37996-0710

165. Frederick Renner, Econergy International Association, 1101 30th Street N.W., Washington, D.C. 20007

166. David Rhinebolt, 1615 M Street NW, Suite 810, National Association of State Energy Officials, Washington, D.C. 20003

167. Martha Rollins, Tennessee Valley Authority, 1101 Market Street, Chattanooga, TN 37402.

168. M. Russell, JIEE, 327 S. Stadium Hall, Knoxville, TN 37996-0710

169. Neil Sampson, American Forestry Association, P.O. Box 2000, Washington,D.C. 20013

170. Roger Sedjo, 1616 P Street, Resources for the Future, Washington D.C. 20036 


\section{EXTERNAL DISTRIBUTION - continued}

171. Jeffrey Serfass, 1800 M Street N.W. Suite 3000 , Utilities for Biomass Energy Commercialization, Washington D.C. 20036

172. Scott Sklar, National Biomass Industries Association, 122 C Street NW, Washington, DC 20001.

173. Goerge Sowers, F. P.E., Senior Vice President, Law Companies Group, Inc., 114 Townpark Drive, Suite 250, Kennesaw, Georgia 30144-5599

174. Dennis Tirpak, Office of Policy Planning and Evaluation, Environmental Protection Agency, $401 \mathrm{M}$ Street, Washington, D.C. 20024

175. Michael Totten, 777 N, Capitol St. NE \#805., Ctr. Renewable Energy And Sustainable Technology, Washington D.C. 20002

176. Mark Trexler, 1131 SE River Forest Road, Milwaukie, OR 97267

177. Jane Turnbull, Electric Power Research Institute, PO Box 10412, Palo Alto CA 94303

178. C. Michael Walton, Ernest $\mathrm{H}$. Cockrell Centennial Chair in Engineering and Chairman, Department of Civil Engineering, University of Texas at Austin, Austin, Texas 78712-1076

179. Edward Williams, Office of Policy, Department of Energy, 1000 Independence Ave., Washington, DC 20585

180. Office of Assistant Manager for Energy Research and Development, DOE-ORO, P.O. Box 2001, Oak Ridge, TN 38831-8600

181-190. OSTI, U.S. Department of Energy, P.O. Box 62, Oak Ridge, TN 37831 